جهود علهماء حائل في خدهة القرآن وعلوهه هن هنتصف القرن الثالث عشر إلى هنتصف القرن الرابع عشر الهجريين

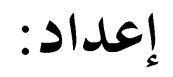

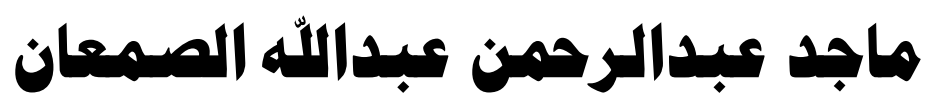

أستاذ الثفسير وعلوم القر آن المساعد في جامعة حائل

$$
\text { IVAY من IVEV }
$$


$1 \vee \leqslant 1$ 


\section{ملخصص البحث}

قامت الأمة الإسلامية على مقتضى سنة الله تعالى في حفظ كتابه؛ بنسخ القر آن الكريم وطباعته

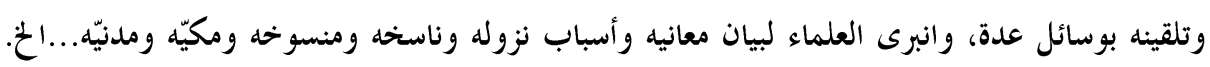

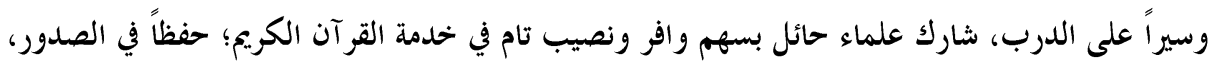

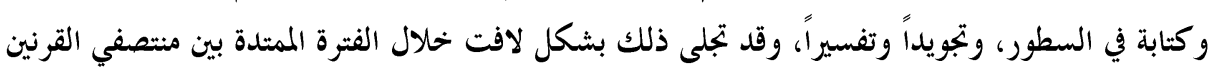
الثالث عشر والرابع عشر الهجريين.

لقد تعددت وسائط تعليم القرآن الكريم وعلومه، فانتشرت كتاتيب البنين والبن البنات، وتولى فئل فيها

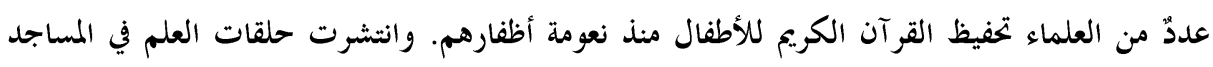

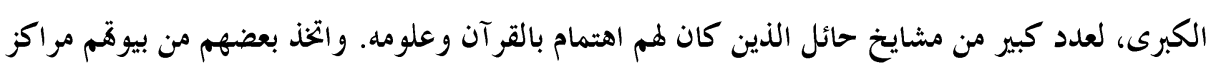

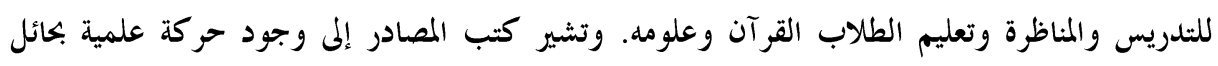
خلال تلك الفترة، وصُفت بأفها جيدة للغاية، واستُقدم إليها معلمون من مصر وسوريا لتعليم الطلاب العلوم

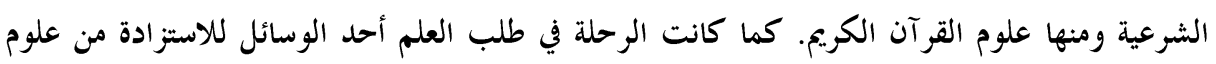

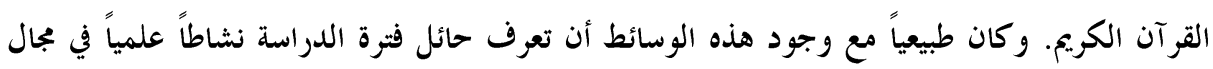

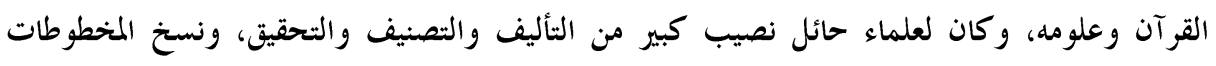
المتعلقة بالقرآن وعلومه. كما كان لأمراء حائل القدح المعلى والثأن العظيم في الاحتفاء بالقر آن وتعظيم

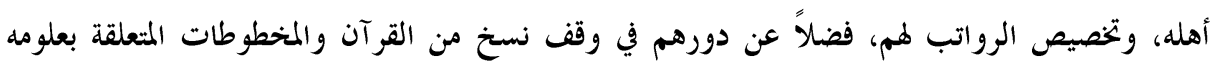

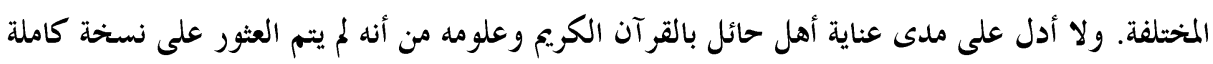

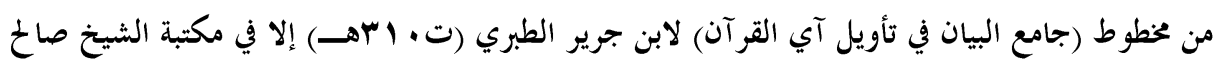

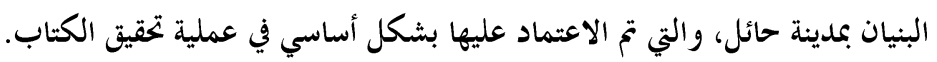

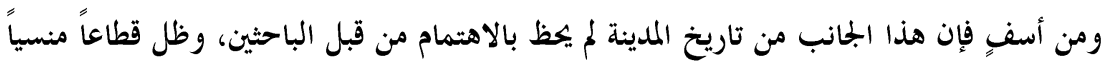

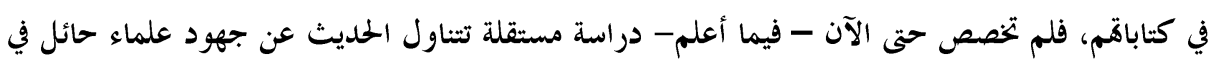

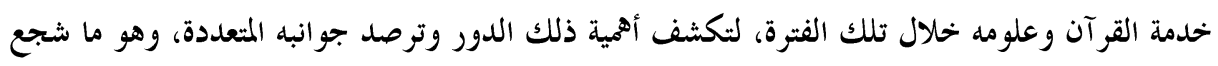
على دراسة هذا الموضوع.

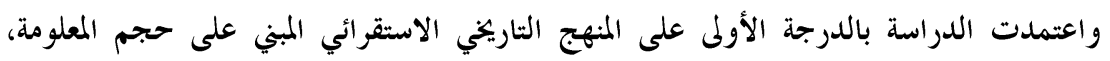

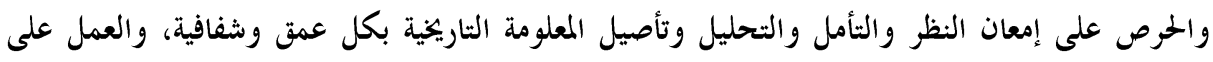

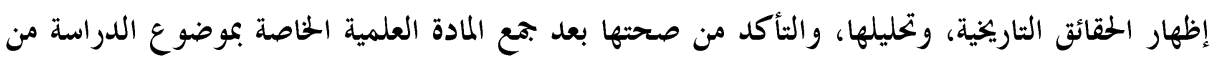




$$
\begin{aligned}
& \text { كلمات مفتاحية: علوم القر آن- حائل. } \\
& \text { ملخص إنجليزي }
\end{aligned}
$$

This research deals with the contribution of Hail to the service of the Holy Quran and its sciences from the middle of the 13 th century to the middle of the fourteenth century AH. It talks about the efforts of the princes under the historical era and the efforts of the scholars and the libraries that covered the manuscripts., In addition to the role of the mosques and mosques in the teaching of the Koran, and in the search revealed the most important libraries and famous manuscripts, and famous scholars of Najd and the extent of their contributions to the service of the Koran.

Keywords: Science Quran - Hail. 


$$
\begin{aligned}
& \text { بسم الله الرحن الرحيم } \\
& \text { المقدمة } \\
& \text { الحمد الله و الصحلاة والسلام على رسول الله وبعد: }
\end{aligned}
$$

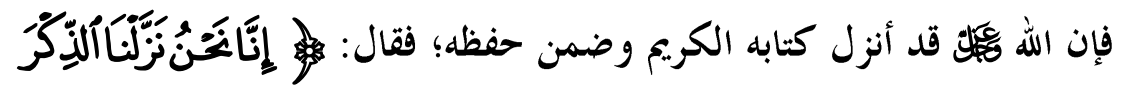

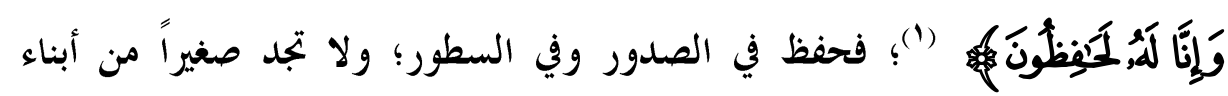

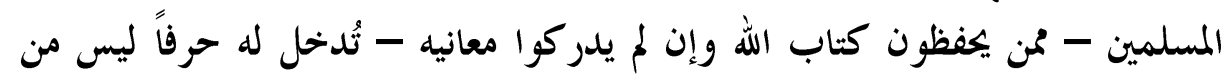
القر آن إلا رفضه و استهجنه لأن أذنه لم تحفظه ولم تتلقه بالقبول

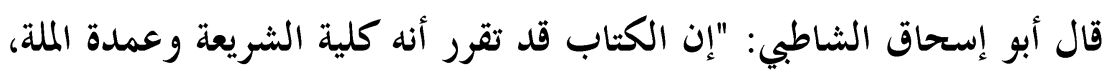

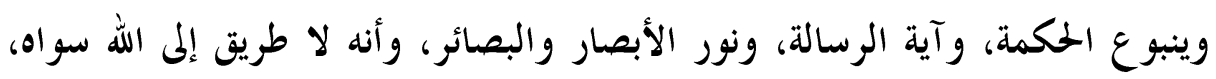

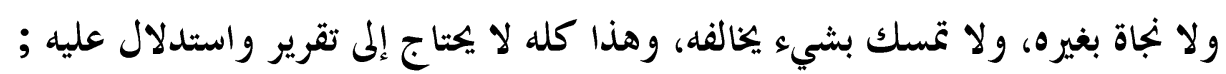

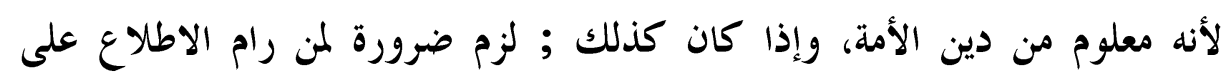

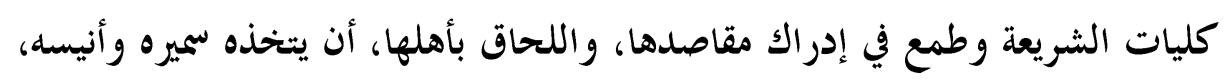

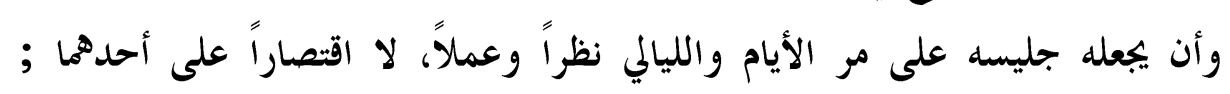

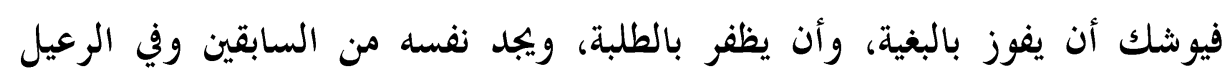

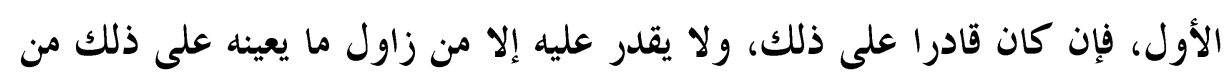

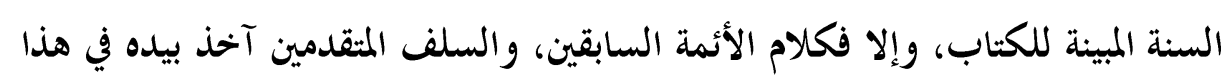

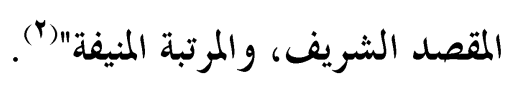

وقامت الأمة الإسلامية على مقتضى سنة الله في حفظ كتابه؛ بنسخ القرآن آن آنسية

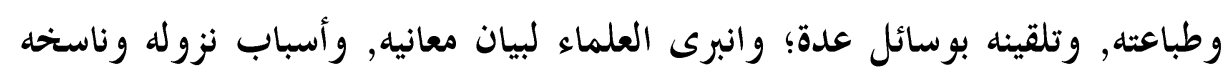

$$
\text { ومنسو خه ومكيه ومدنيه.... }
$$

ولقد ضرب علماء حائل بسهم وافر , ونصيب تام في خدمة القر آن؛ حفظاً في

$$
\begin{aligned}
& \text { (') (') سورة الحجر آية: }
\end{aligned}
$$

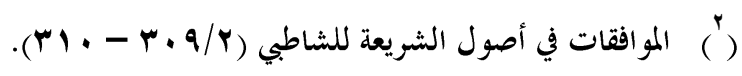


الصدور وكتابة في السطور , وتفسيراً وتجويداً وقراءات ونسخا وأوقافا .

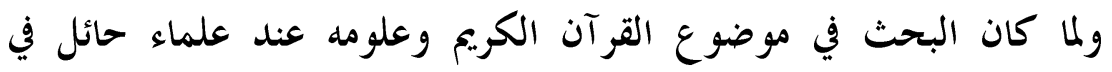
منتصف القرن الثالث عشر إلى منتصف القرن الرابع عشر الهجريين حاولت بقدر الإمكان أن أستعرض أهم العلوم القر آنية التي برزوا فيها بقدر ما يسمح به البحث البحث. ومما تجدر الإشارة إليه أن التنقيب عن العلماء والكتب التي اعتنى أصحاهيا بالقر آن يكتسيه بعض الصعوبة والرَّهق وذلك لأسباب منها:

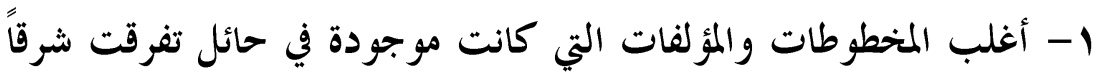
وغرباً؛ مما نجد مشقة في الوصول إليها. Y - عدم وجود دراسات كتم بالقر آن وعلومه في حائل، فلم تخصص حتى الآن - فيما أعلم- دراسة مستقلة تتناول الحمديث عن جهود علماء حائل في خدمة وردة القر آن وعلومه خلال تلك الفترة، لتكشف أهمية ذلك الدور وترصد جوانبه المتعددة، وهو ما شجع على دراسة هذا الموضوع. وسوف تعتمد الدراسة بالدرجة الأولى على المنهج التاريخي الاستقرائي المبني

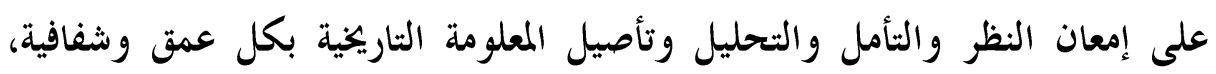

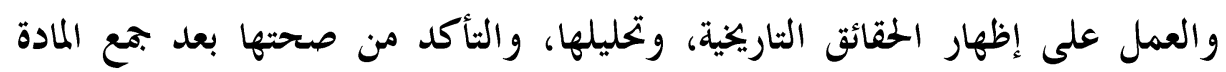
العلمية الخاصة بموضوع الدراسة من منابعها الأصلية. واقتضت طبيعة البحث أن أقسمه إلى:

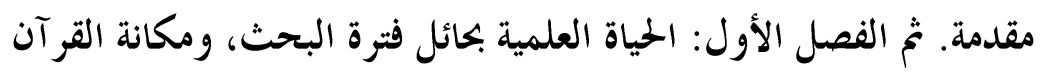

$$
\text { وعلومه فيها، وفيه مبحثان : }
$$

المبحث الأول: اعتناء علماء حائل بتحفيظ القر آن للأطفال. المبحث الثالي: اهتمام أمراء حائل بالقر آن وتشجيع العلماء على ذلك. الفصل الثالي: وسائط تعليم القر آن الكريم وعلومه في حائل، وفيه ثلاثة مباحث: المبحث الأول: الكتاتيب القر آنية في حائل. 


$$
\text { المبحث الثالي: المدارس القر آنية في حائل. }
$$

المبحث الثالث: الرحلات والإجازات العلمية لعلماء حائل.

الفصل الثالث: عناية علماء حائل بالقر آن الكريم وعلو مه، وفيه مبحثان:

المبحث الأول: عناية علماء حائل بالقر آن الكريم تفسيراً وبياناً.

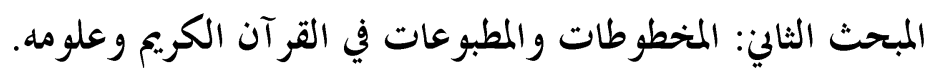




\section{الفصل الأول}

\section{الحياة العلمية بحائل فترة البحث ومكانة القرآن وعلومه فيها}

$$
\text { وفيها مبحثان: }
$$

المبحث الأول: اعتناء علماء حائل بتحفيظ القر آن للأطفال. المبحث الثالي: اهتمام أمراء حائل بالقر آن وتشجيع العلماء على ذلك.

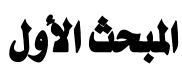

\section{اعتناء علماء حائل بتحفيط القرآن للأطفال}

لقد اهتم علماء حائل بتحفيظ كتاب الله تعالمى للأطفال منذ نعومة أظفارهم؛

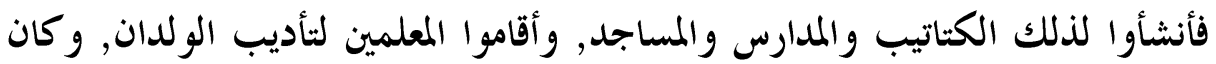

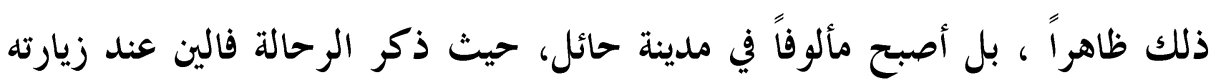

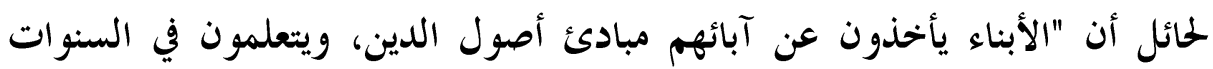

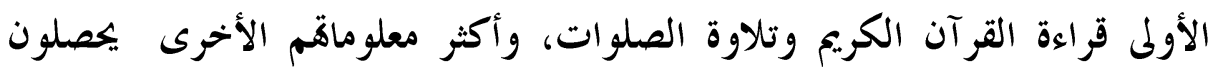
عليها شفويا من المعمرين الذين لا يبعد عنهم الصغار" (1").

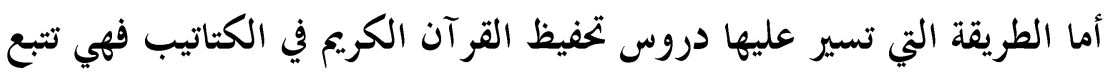

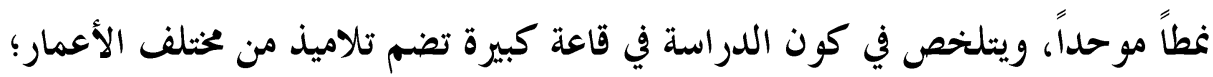
ويجلس الجحدد أمام الشيخ والقدامى وراءهم؛ ويجلسون على الحصير؛ وقد حفلت

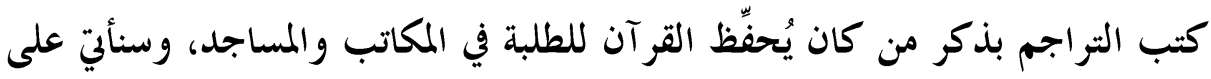
ذكر بعضٍ منهم لاحقاً.

أما عن مدة الدراسة، فيبدو أها لا توتبط بمدى زمني معين وإنما تعتمد على

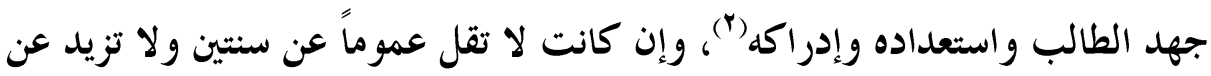

$$
\text { (') انظر : صور من شمالي جزيرة العرب للرحالة فالين (ص V. (1). }
$$

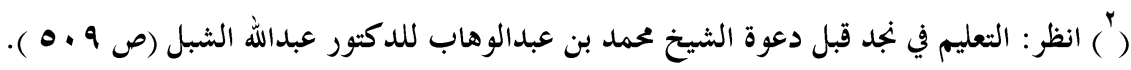


ست سنوات(")، لا سيما إذا ما أراد الطالب حفظ القرآن الكريم كاملاً مع تجويده("). على الرغم من بساطة التعليم في هذه الكتاتيب أو دور التحفيظ، إلا أذها كانت تتناسب ولا شك مع ظروف ذلك العصر، ونجحت في إخراج العديد من العلماء الذين أثروا الحياة العلمية في شتى أنحاء العالم العربي. ولقد كان يُطلق على معلم الكتاتيب لقب "المطوع"، ومن أهم صفاته أن يكون حافظاً

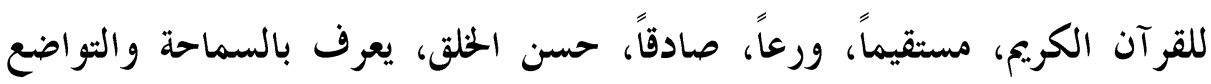
والوقار والزهد والميبة إلى جانب العلم الوافر وحسن الخط، وتتوفر في بعض كتب

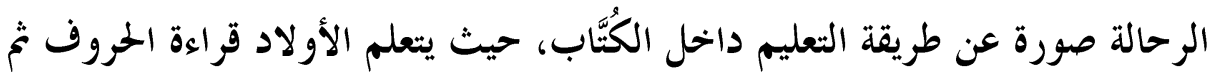
يقوموا برسم أشكالها بأقلام الكلس على سبورة صغيرة سوداء. ونتيجة انتشار

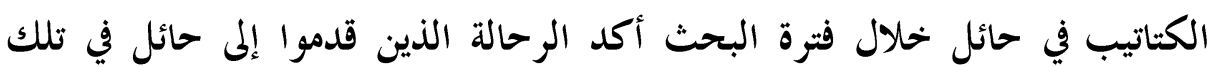

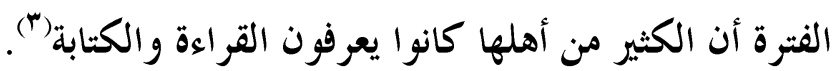

$$
\text { (') انظر: الإصلاح الاجتماعي في عهد الملك عبدالعزيز لعبدالفتاح أبو علية (ص9 ب). }
$$

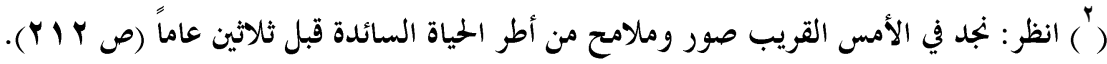

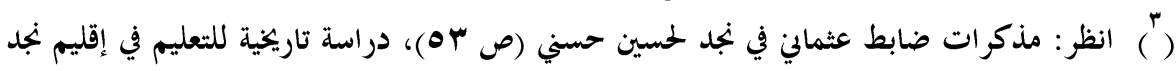

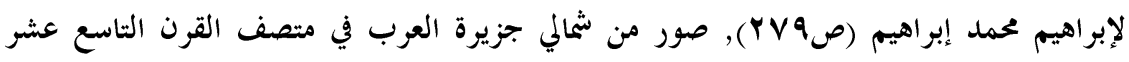

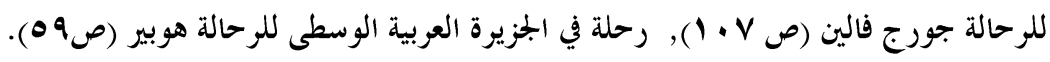




\section{المبحث الثاني}

\section{اهتعاه أمراء حائل بالقرآن وتشجيع العلماء على ذلك}

لقد عرفت حائل في عهد آل رشيد هضة علمية وحضارية عظيمة نشهدها من

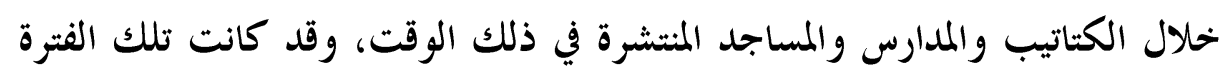
هي امتداد لأوضاعها في عهد الدولة السعودية الثانية، وعلى الرغم من حدوث

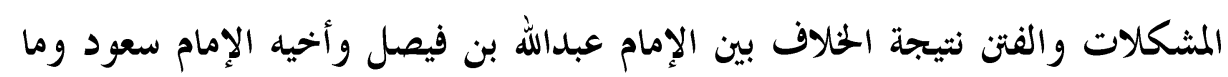

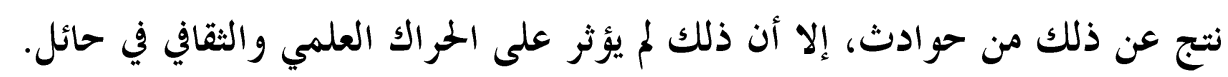

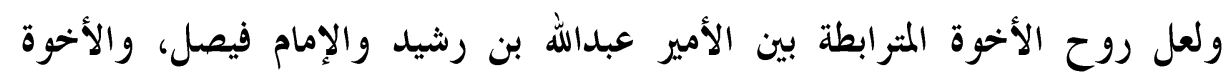

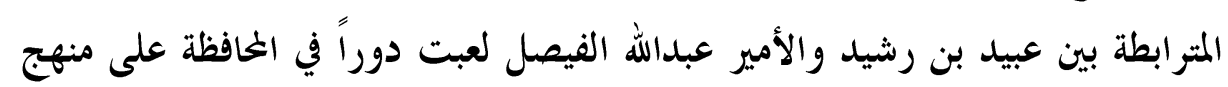
الدعوة الإصلاحية وتطبيقه في حائل.

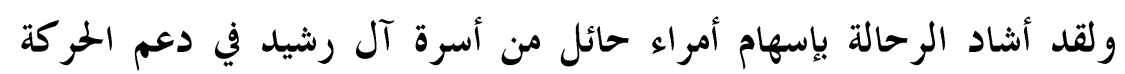

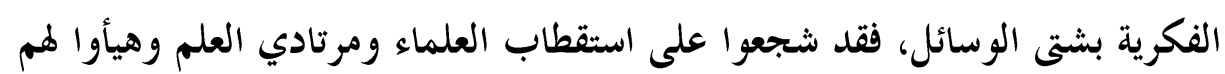

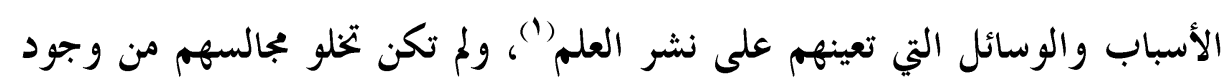
علماء وأدباء (r)، وحلقات للمذاكرة والمناظرة (َ).

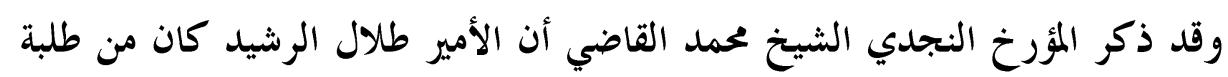

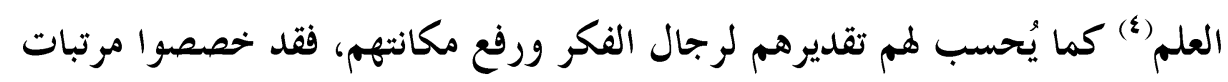

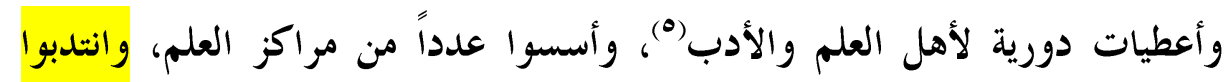

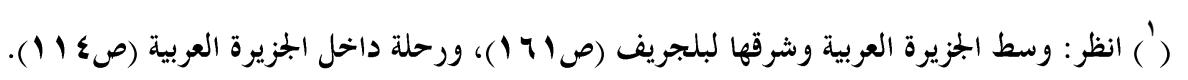

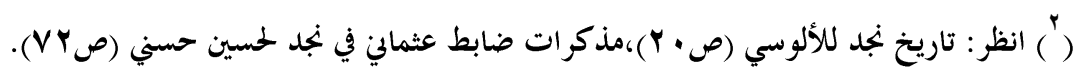

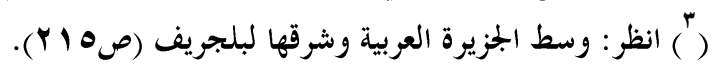

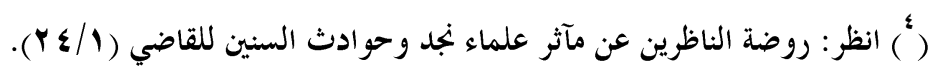

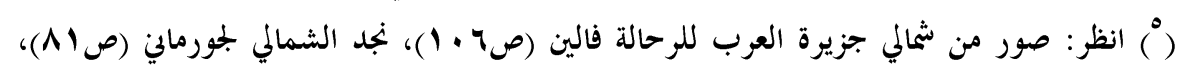

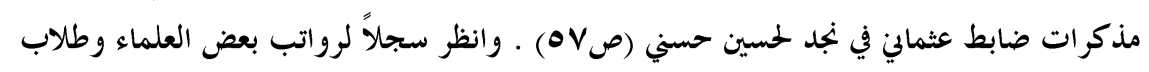
العلم من أهل حائل محفوظ في مكتبة البنيان/دون رقم. 
إليها المعلمين من سوريا ومصر، واستقطبوا إلى حاضرقم القضاة من المراكز الأكثر

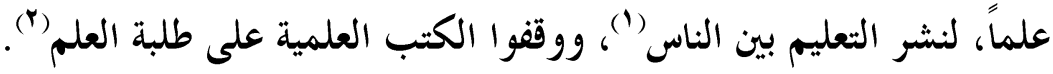

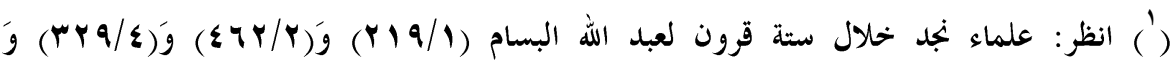
. ( $997 / 4)$ ( ) ") تنتشر وقفياقم في العديد من مكتبات حائل بشكل يسمح بياجر اء دراسة منفردة. 


$$
\begin{aligned}
& \text { الفمل الثاني } \\
& \text { وسائط تمليم القرآن الكريمووماومه في حائل } \\
& \text { وفيه ثلاثة مباحث: } \\
& \text { المبحث الأول: الكتاتيب القر آنية في حائل. } \\
& \text { المبحث الثاين: المدارس القر آنية في حائل. } \\
& \text { المبحث الثالث: الرحلات والإجازات العلمية لعلماء حائل. }
\end{aligned}
$$




\section{المبحث الأول \\ الكتاتيب القرآية في حائل}

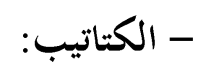

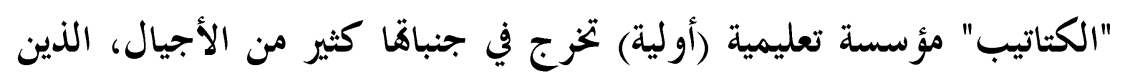

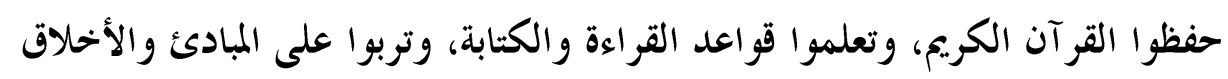

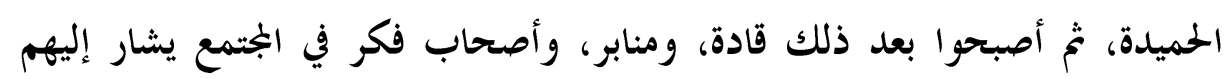

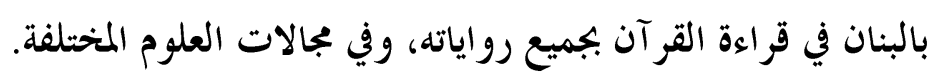

$$
\text { والكتاتيب في اللغة: }
$$

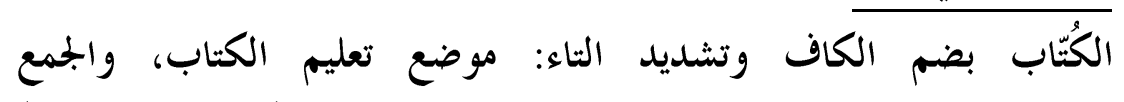

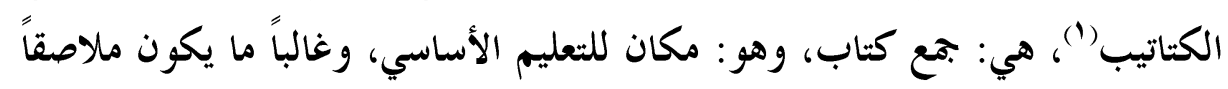

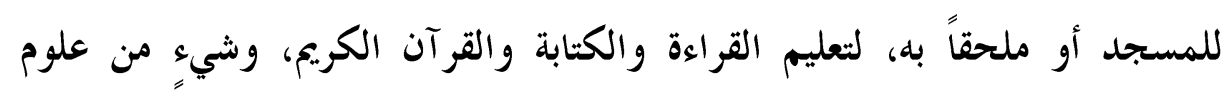

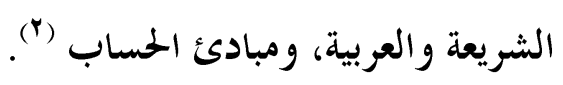

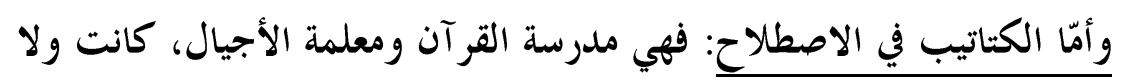

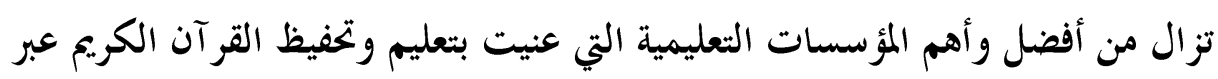

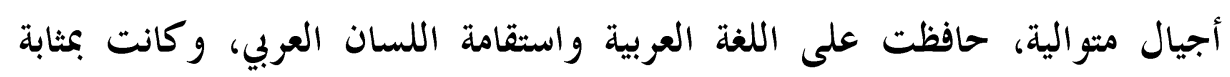

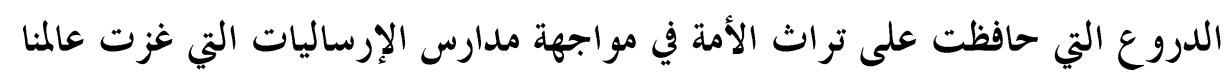

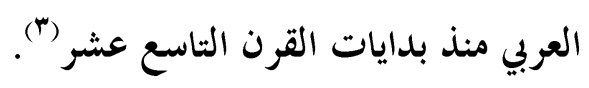

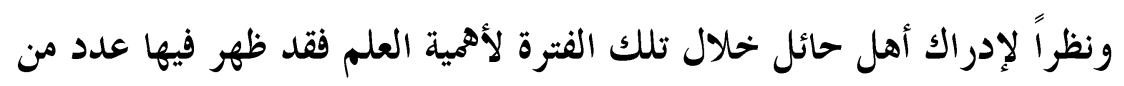

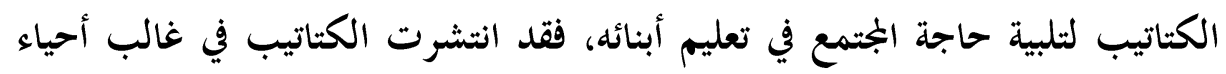

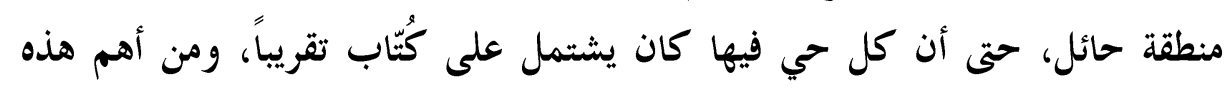

$$
\text { ( ') انظر : آداب المعلمين لابن سحنون (صع ج). }
$$

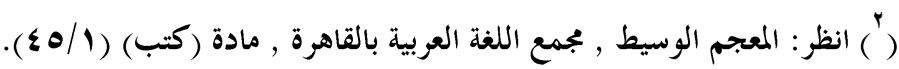

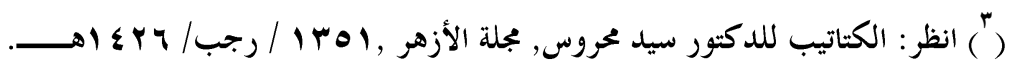




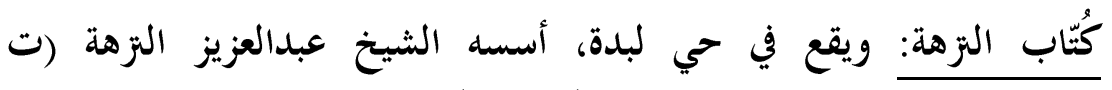
اله MTV الأداء") تخخج على يديه عدد من الحفاظ منهم الأمير عبدالعزيز بن إبراهيم البراهيم

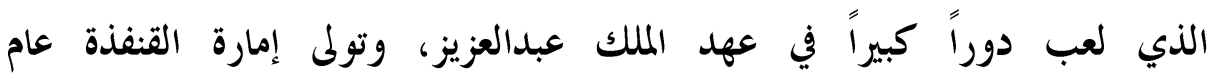

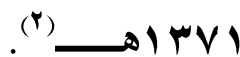

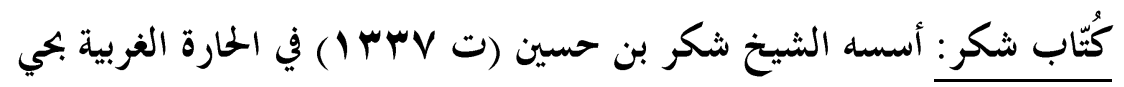

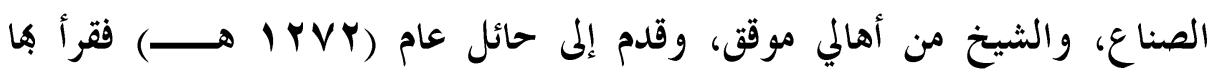

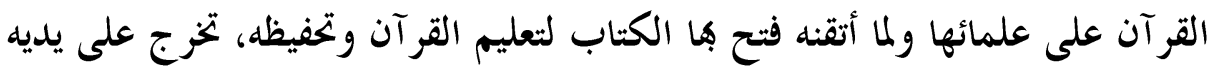

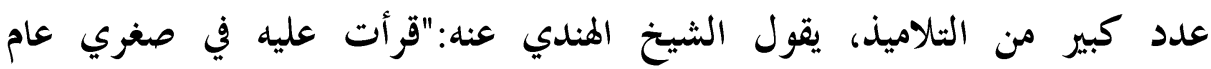
اله MTV

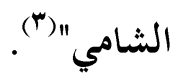

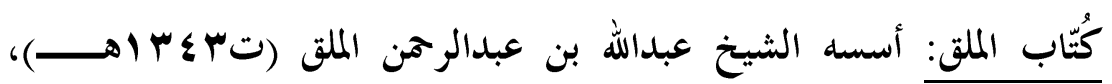
ويقع في حي لبدة، حيث كان الشيخ من حفاظ القرآن البجودين، ودرس على على يديد عدد من التلاميذ (\&).

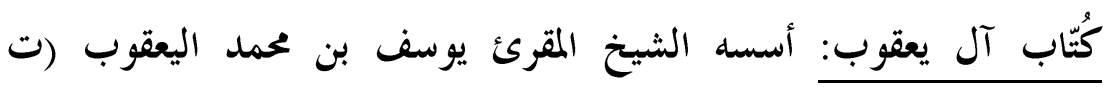

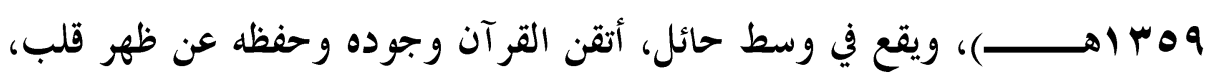
وبلغ مرتبة متقدمة في الإقراء، مكنته من تدريس الطلاب القر آن وتجويده في جامع

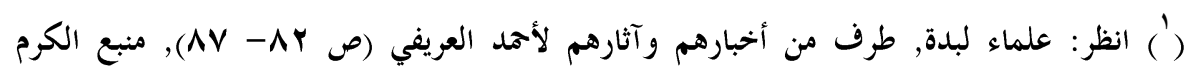

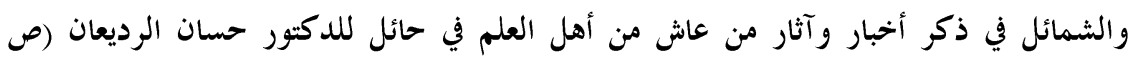

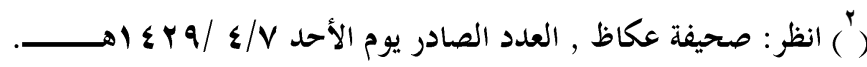

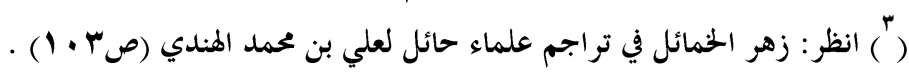

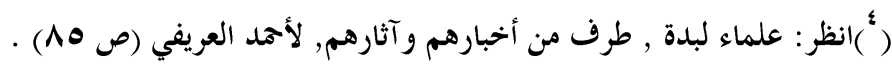




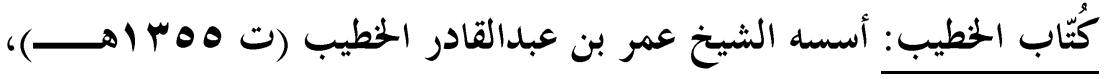

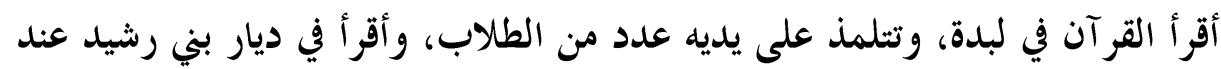

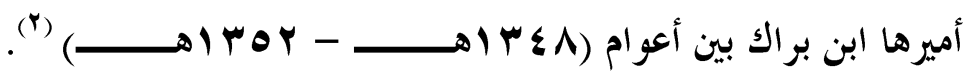

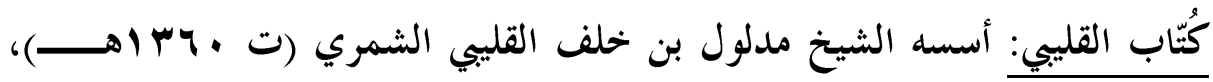

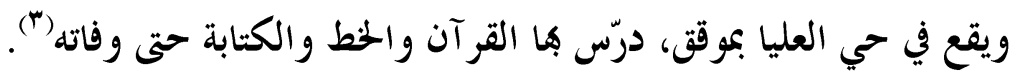

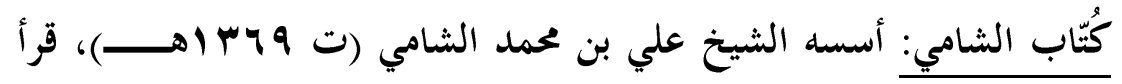

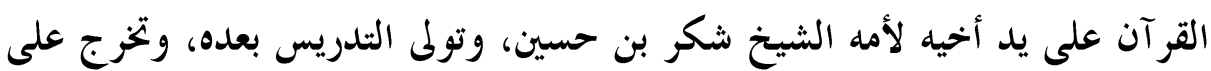
يديه عدد من الطلاب (\&).

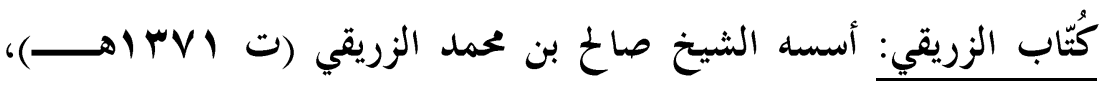

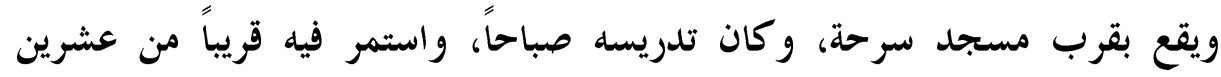
سنة (•) بعر

ولم تقنصر الكتاتيب على الرجال فقط في حائل، بل شاركت المرأة، فظهرت

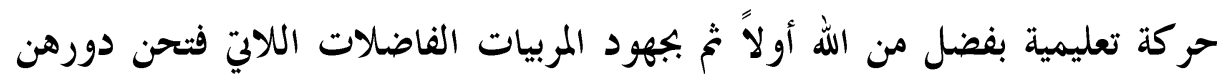
لحدمة العلم وتدريس بنات حائل في كتاتيبهن، ومن أشهر كتانيب البنات في حائل:

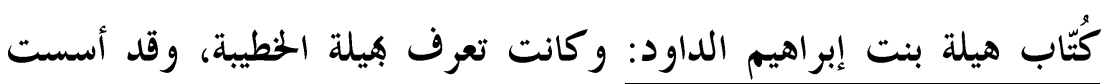

(') انظر: زهر الخمائل في تراجم علماء حائل لعلي بن محمد الهندي (صع 1) , الثقافة والتعليم

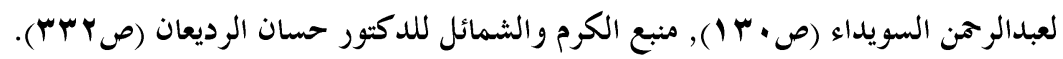

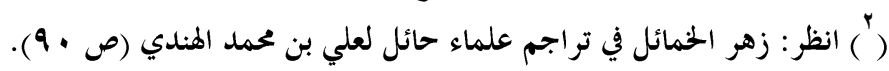

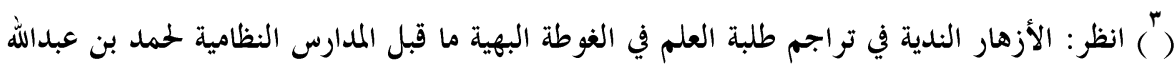

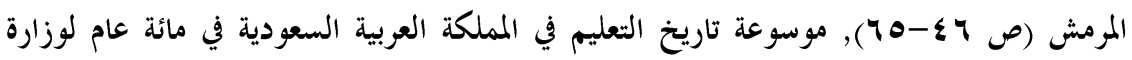

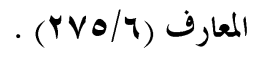

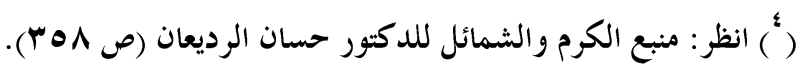

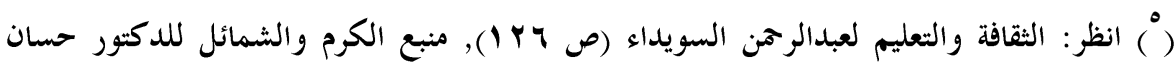

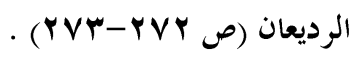


كُّنّاجها في بيتها في حي لبدة، وكانت تدرس للبنات القرآن الكريم تلاوةً وحفظاً،

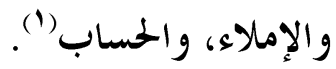

كُثّاب نورة بنت محمد الهريش: تعلمت القرآن على يد أمها هيلة الداود، وبعد

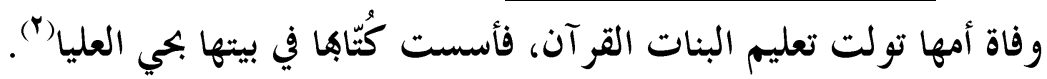
كُّثاب هيا بنت صالح الشاعر: نشأت في بيئة علمية، فوالدها من حفّاظ آنّات القر آن، وصفه الهندي بقوله:" كان آية في حفظه وتجويده"(")، أسست كُّنّابها في متزلها في حي لبدة، وكانت تدرس فيه القرآن الكريم لعدد من الفتيات، وكانت تدرسهن في ولي الصباح إلى آذان الظهر (\&). وقد أسهمت هذه الكتاتيب في ازدهار الحر كة العلمية في حائل فخرجت ادران عدداً من

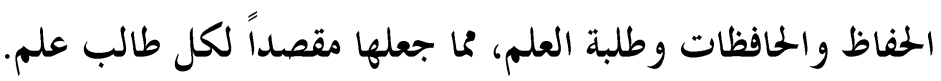

( ') انظر : علماء حائل لأحد العريفي (ص Y + (1), الثقافة والتعليم لعبدالرحن السويداء (ص ع ب).

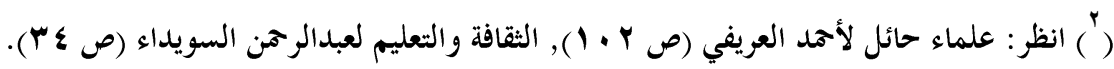

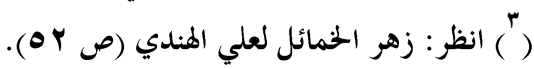

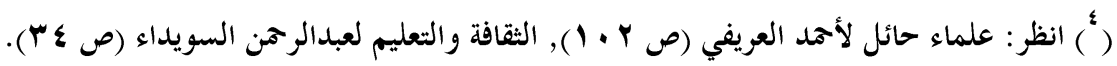




\section{المبحث الثاني الماني \\ المدارس القرآنية في حائل}

تعتبر الكتاتيب بمثابة المرحلة التمهيدية، فمن أتقن القراءة والكتابة وقرأ القر آن

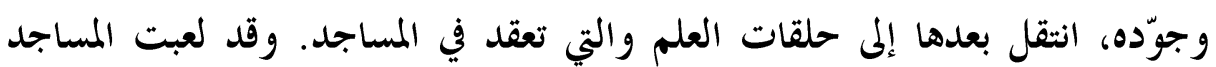

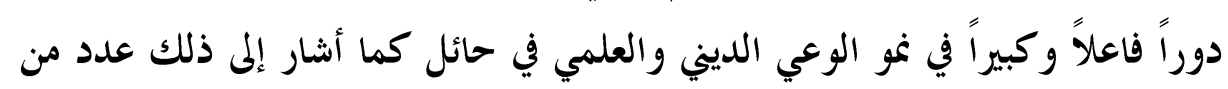

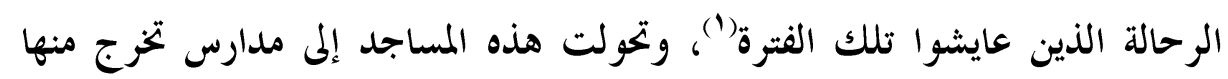
طلبة العلم الذين يتولون نشر الدعوة بين الناس، والقيام بالمناصب الدينية التي يحتاج الناس إليها من بادية وحاضرة. و ومن أشهر تلك المدارس في حائل في تلك الفترة: لئل مدرسة قصر برزان: وهي أشبه بالمدرسة الحخاصة ؛ حيث يدرس فيها فيها أبناء أسرة

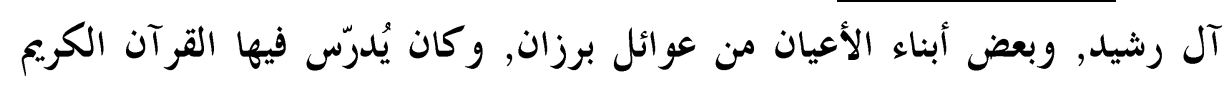

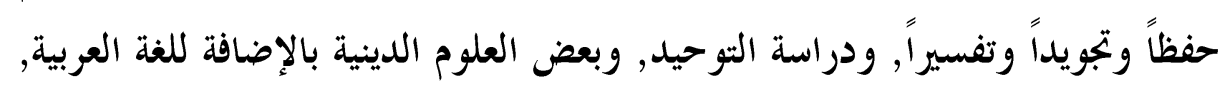

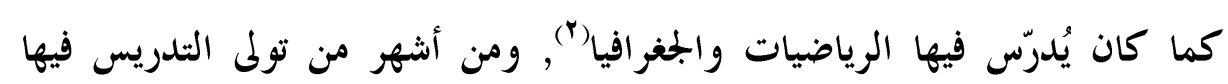
الشيخ جار الله الحماد, والشيخ عوض الحجي, والشيخ صالح البنيان(").

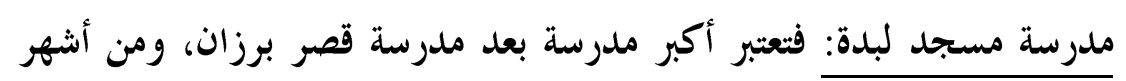

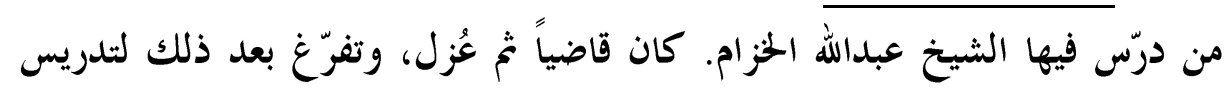
العلم في مسجد لبدة، وقد تخرّج على يديه عدد كبير من طلبة العلم (\&).

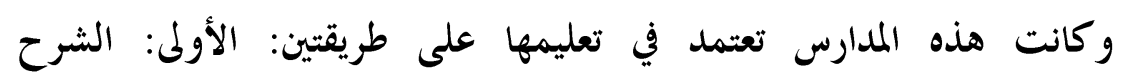

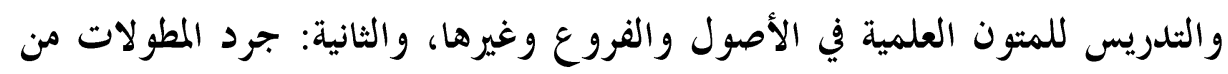

(') انظر: الرحالة الأوربيون في شنمال الجزيرة العربية لعوض البادي (1/1) إك).

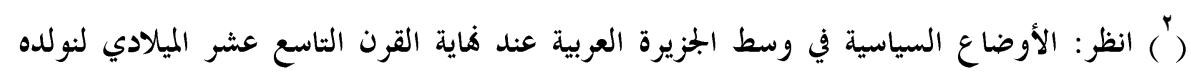

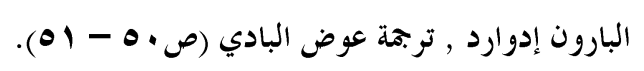

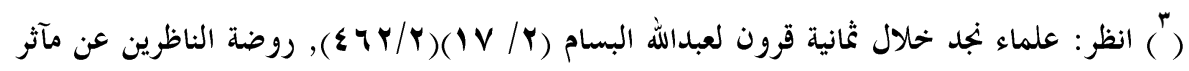

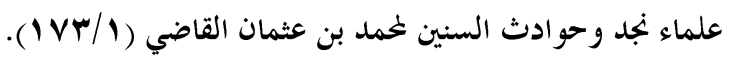

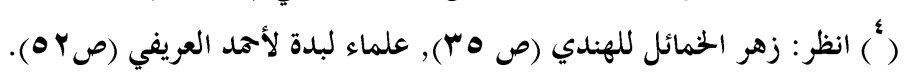


الكتب العلمية كالتفسير والسنن وكتب ابن تيمية وابن القيم، وغيرها(1)، ومن أبرز

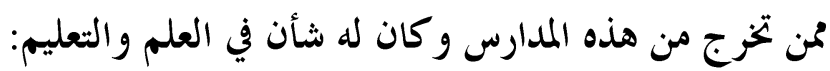

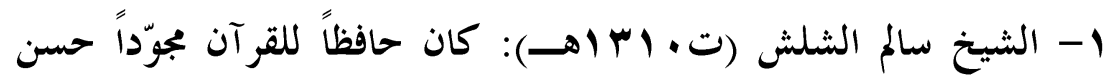
الصوت والتلاوة، كان خطاطاً كتب بقلمه كتباً كثيرة، درس على مشايخها، وكان الثان يلقب بالنقيظان (َ).

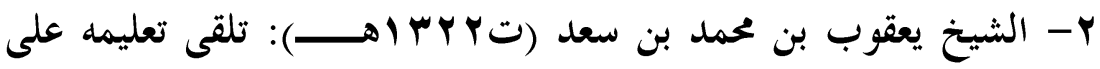
الشيخ عوض الحجي. وقد امتنع عن القضاء وتفرّغ للثدريس (").

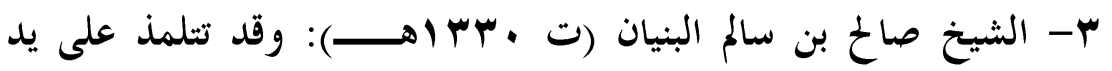

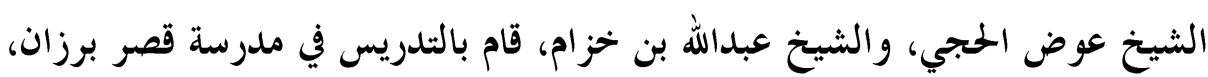

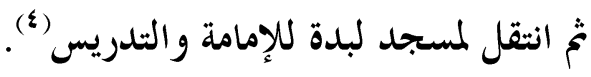

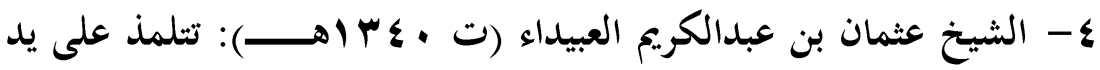
الشيخ عوض الحجي، وتولى القضاء ثخ اعتذر ليتفرغ للتدريس (•).

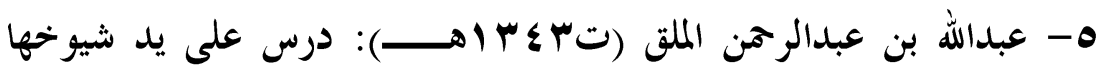

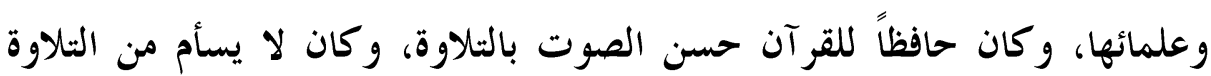

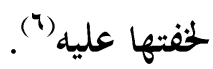
צ- حسن بن محمد الحجي (ت ع ب اهــــ): قرأ القرآن والتجويد على

$$
\begin{aligned}
& \text { (') انظر : منبع الكرم و الشمائل للرديعان (صه \&). }
\end{aligned}
$$

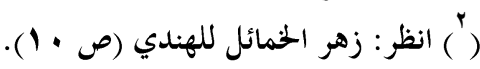

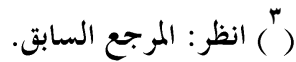

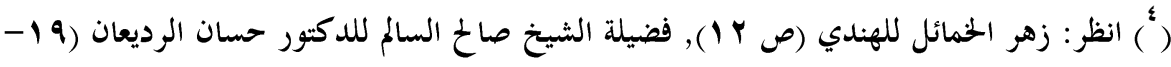

$$
\begin{aligned}
& \text { ( ) انظر: زهر الحمائل للهندي (صه 1). }
\end{aligned}
$$

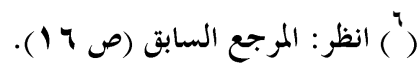


أخيه عوض الحجي، كان مولعاً بالكتب واقتنائها'".

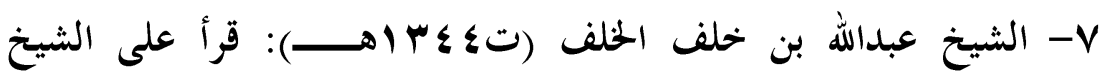

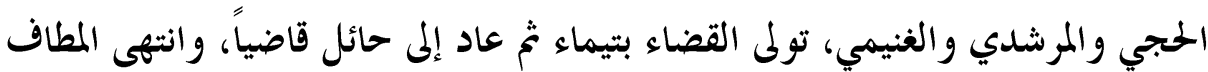

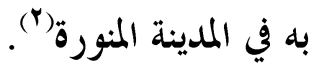

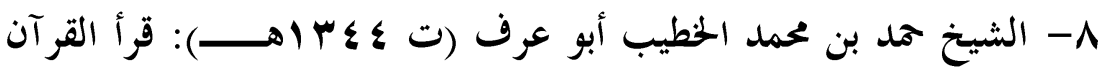

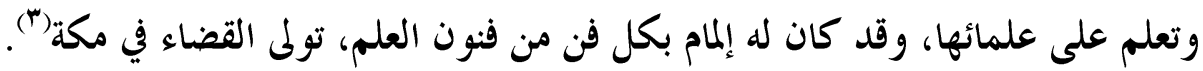

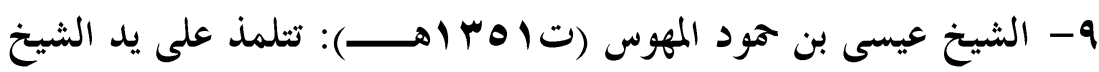
عوض الحجي، وعرض عليه القضاء وامتنع، تفرغ للثدريس فكان له درس بعد صلاة

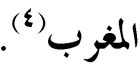
الشيخ محمد بن حيد الصريري (تمهـ إهـــــ : أخذ العلم عن الشيخ صالح السالم البنيان , الشيخ عبدالله بن عبداللطيف آل الشيخ , تولى القضاء في موقن إلى أن أعفي منه (•)

(') انظر : زهر الحمائل للهندي (صه (1), شعر اء الجبل للسويداء (19). (19).

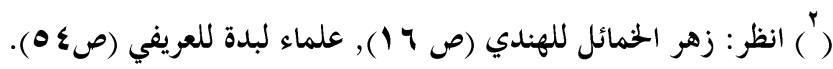

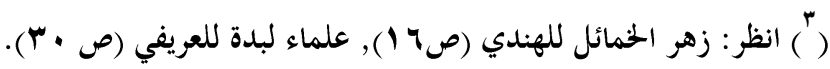

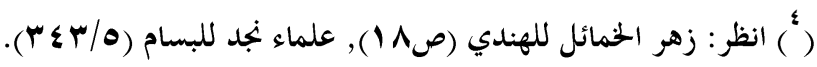

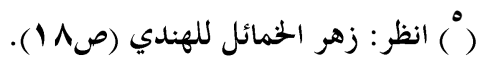




\section{المبحث الثالث}

\section{الرحلات والإجازات المطمية لملماء حاثل}

تعتبر الرحلة في طلب العلم من وسائل تحصيله، يتبعها الطالب بعد أن ينهي

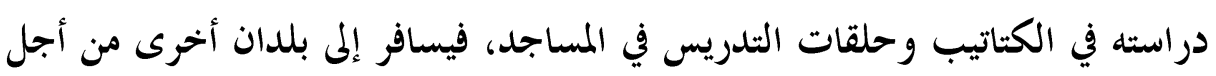

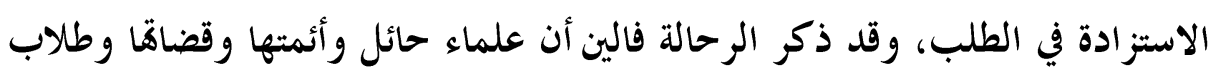
العلم فيها كانوا يتلقون ثقافتهم في المدينة المنورة، أو في القاهرة، أو في الرياض، أو الو في

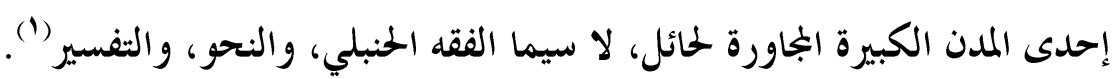
ومن علماء حائل الذين رحلوا لطلب العلم تخ عادوا للتدريس فيها:

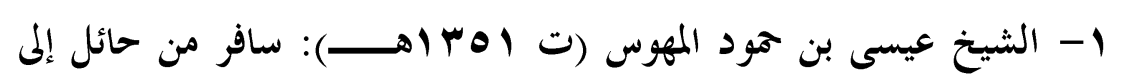

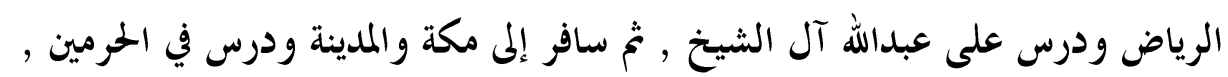

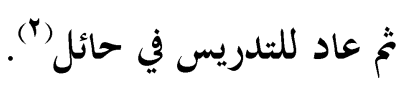

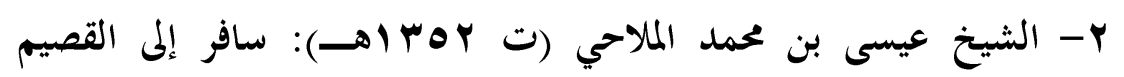
ودرس فيها (").

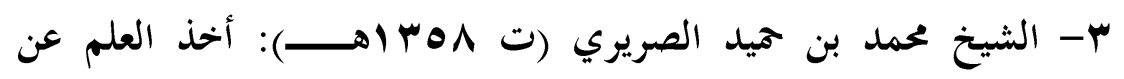

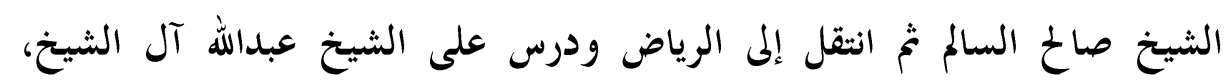

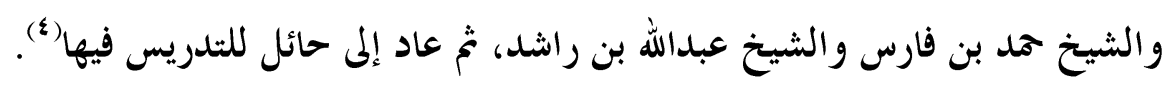

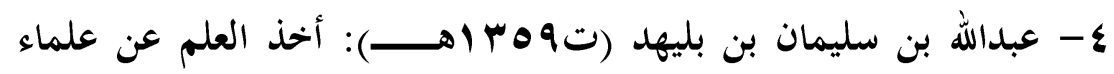

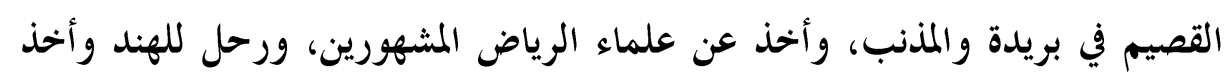
عن علمائها وتمت إجازته ثم عاد إلى حائل (•).

$$
\begin{aligned}
& \text { (' (' انظر : صور من شمالي جزيرة العرب في منتصف القرن التاسع عشر (ص ؟ + 1). }
\end{aligned}
$$

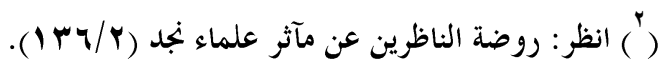

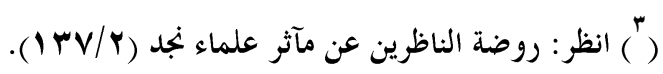

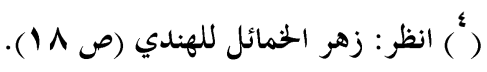

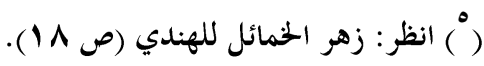




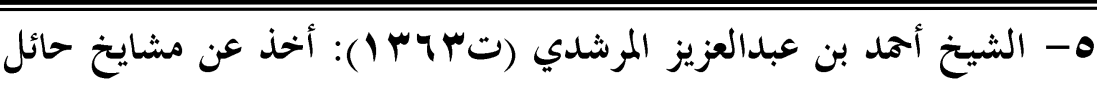

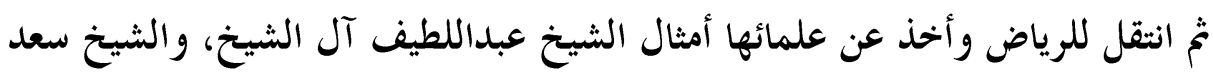

$$
\text { بن عثيق، والشيخ حمد بن فارس (1) }
$$

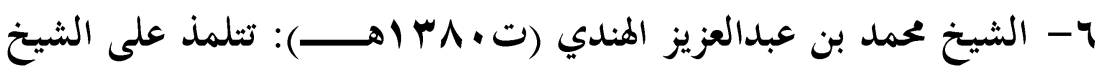

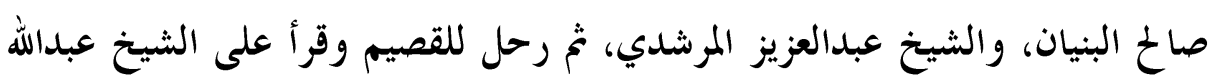

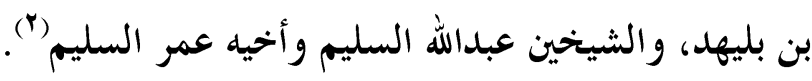

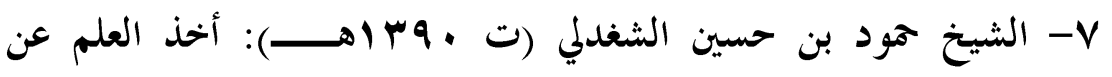
الثيخ صالح البنيان، ثم رحل إلى الرياض ودرس على الثيخ حمد بن فارس والثيخ عبدالله بن عبداللطيف آل الثيخ حتى صار من أكابر العلماء (َ). وقد حصل عدد من أهل العلم في حائل على إجازات علمية، منهم:

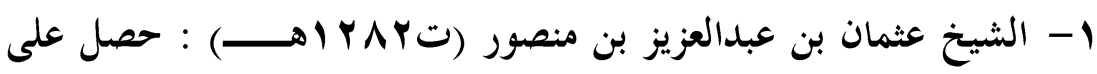
إجازة علمية في الفقه والحساب والتفسير والحديث والآداب والفرائض من الثيخ محمد بن سلوم الفرضي الثهير (\&).

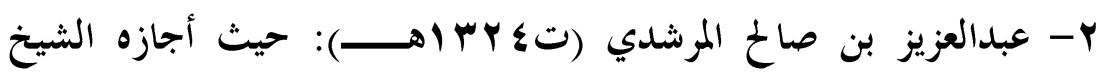
عبدالرمن بن حسن بن محمد بن عبدالوهاب برواية الصحيحين في الحديث, والثاطبية

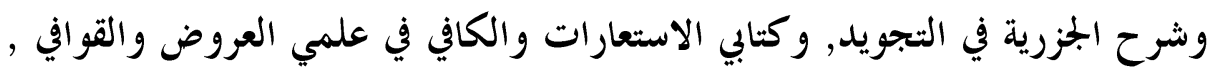

$$
\text { وكتاب التوحيد , وغيرها من فنون العلم (ه). }
$$

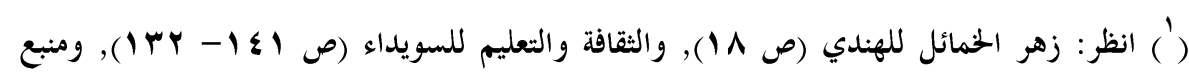

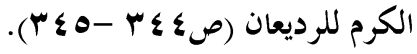

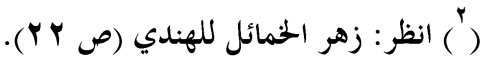

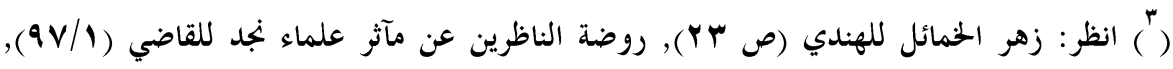

$$
\begin{aligned}
& \text { حديث الوثائق لعبدالرزاق الشغلي (ص ب ؟ ؟). }
\end{aligned}
$$

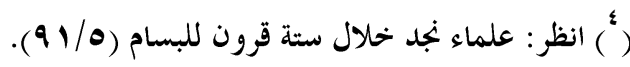

$$
\begin{aligned}
& \text { ( ) انظر : لدى الدكتور حسان الرديعان صورة من الإجازة. }
\end{aligned}
$$


1871

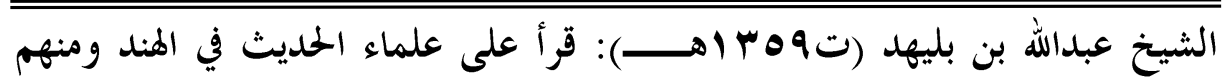

المسند عبدالستار الدهلوي ,وتت إجازته إجازة عامة بشتى العلوم وعلى وجه

الخحصوص علم الحمديث (1)

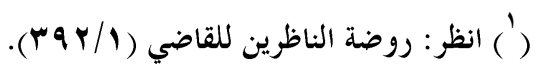




\section{الفمل الثالثالث}

عناية علماء حاثل بالقرآن الكريمووملومه

وفيه مبحثان:

المبحث الأول: عناية علماء حائل بالقر آن الكريم تفسيراً وبياناً.

المبحث الثالي: المخطوطات والمطبوعات في القر آن الكريع وعلومه. 


\section{المبحث الأول}

\section{عناية علماء حائل بالقرآن الكريم تفسيراً ويياناً}

التفسير علم يعرف به معنى كلام الله المعجز المتزل على نبيه محمدٍ بتلاوته.

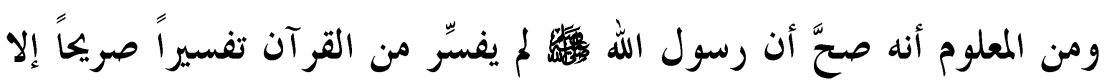
آيات معدودة، ثم اجتهل بعد ذلك العلماء جيلاً بعد جيل في عامة الأمصار بدئا

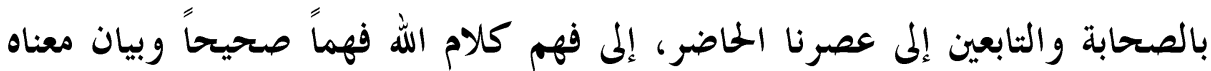

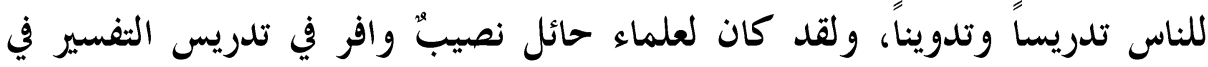
المدارس والمساجد وفي اللقاءات الحاصة، أما التدوين فلم تسعفنا المراجع التي بين أيدينا مع قلتها عن شيء من ذلك.

ومما يمكن أن نستدل به على عندية علماء حائل في علم التفسير هو توافر أمهات كتب التفسير المخطوطة والمطبوعة في مكتبات حائل الحخاصة، كابن جرير الطبري، ومعالم التزيل للبغوي، وأنوار التزيل للبيضاوي، ولباب التأويل للخازن، إنهي

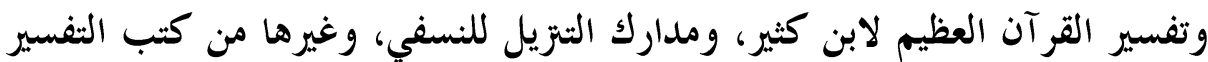
التي امتلأت بها مكتبات علماء حائل الحخاصة. وقد كان التفسير في المساجد والمدارس شائعاً بين العلماء البارزين؛ وممن اشتهر الثاءلة بذلك: صالح السالم البنيان(')، وعبدالله بن بليهد(")، وعودة بن عمير المرمش (")، حود

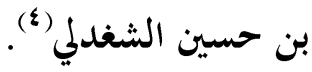
ومعظم المفسرين للقر آن الكريم في مجالس الدروس كانوا يكررون في الغالب

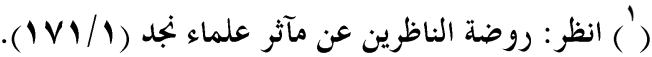

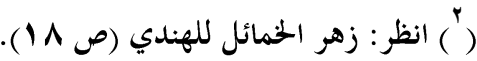

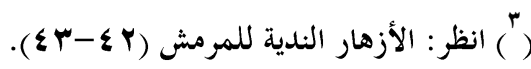

$$
\begin{aligned}
& \text { ( ) انظر : حديث الوثائق لعبدالرزاق الشغدلي (ص ب ؟ ع). }
\end{aligned}
$$


أقوال المفسرين المتقدمين، كما أن المراجع تعوزنا عن طريقة هؤلاء في التدريس. ولقد اتسم علماء حائل بالحب الشديد للعلم والحرص على نشره والمثابرة والتفابي في

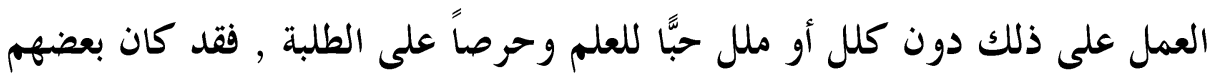
يبدأ في تعليم القرآن الكريم بعد الفجر إلى شروق الشمس, وبعد الظهر يدرس لهر التفسير (1)

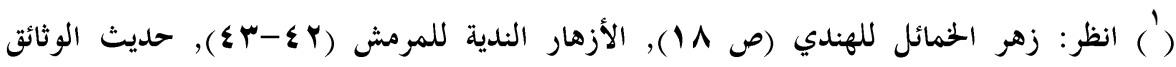
لعبدالززاق الشغللي (ص ب ؟). 


\section{المبحث الثاني \\ المخطوطات والمطبوعات في القرآن الكريم وعلومه}

انتشرت المكتبات الخخاصة في حائل خاصة ونجد عامة خلال هذه المدة، ولعل

من أسباب ذلك موقع حائل الاستراتيجي، حيث إفا طريق الحاج العراقي، الذي

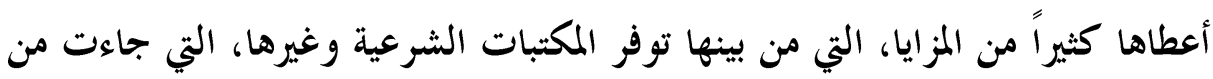

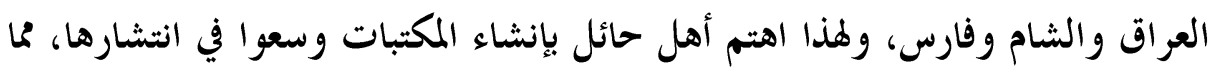
أدى إلى تفردها بنسخ نادرة من المخطوطات في وجيع الفنون.

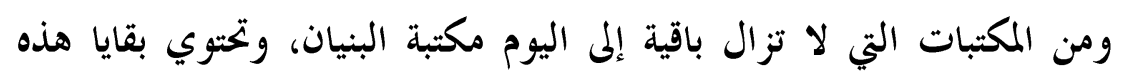

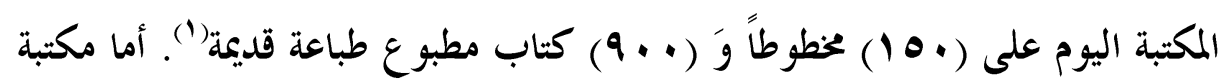
اليعقوب التي آلت إلى مكتبة المعهد العلمي بحائل فقد تبقى منها ما يزيد على على أربعمائة

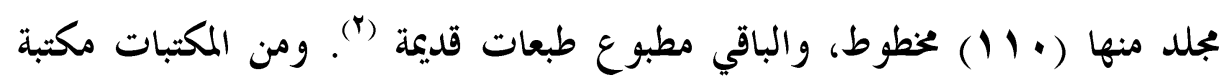

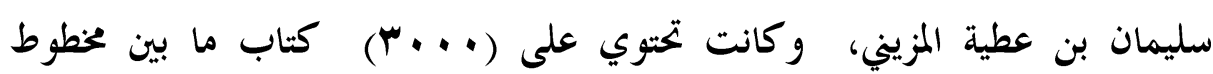

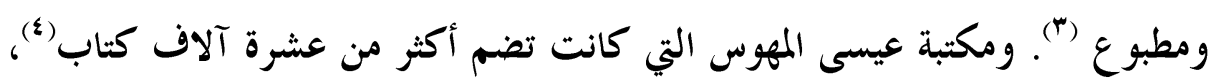

$$
\text { وغير ذلك من المكتبات الخاصة(•). }
$$

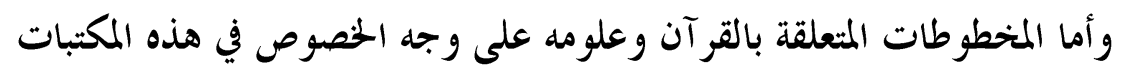

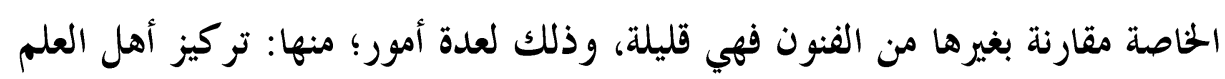

$$
\begin{aligned}
& \text { (') انظر : الثقافة والتعليم لعبدالرمن السويداء (ص • (7). }
\end{aligned}
$$

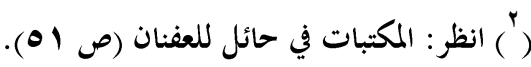

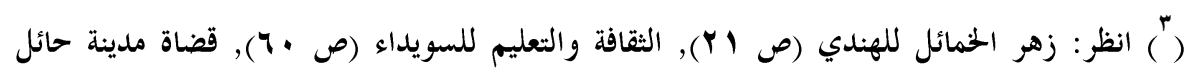

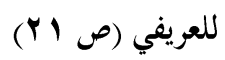

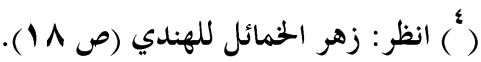

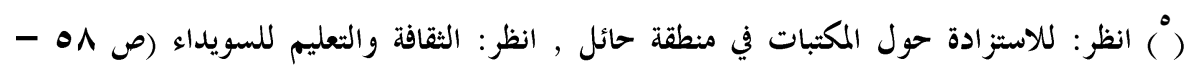

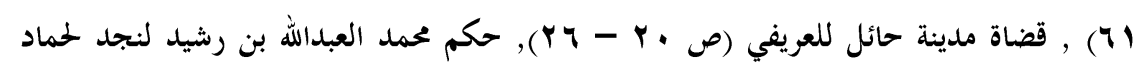

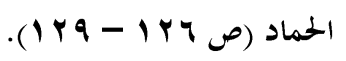


في ذلك الوقت على الاهتمام ببعض العلوم لحاجتها كالعقيدة والفقه والحديث .

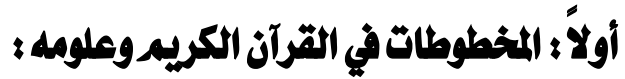

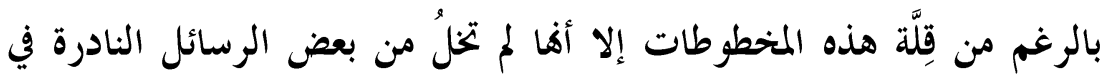

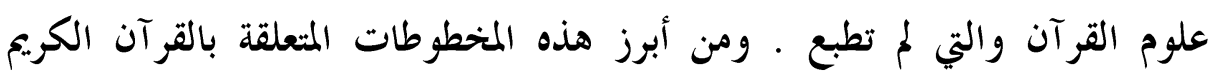

$$
\text { وعلومه في مكتبات حائل: }
$$

ا- جامع البيان في تأويل آي القرآن لابن جرير الطبري (ت • اباه)، وهو

أشهر مخطوط يُتحدث عنه في مكتبات حائل (1).

r- قطعة من معالم التنزيل لأبي محمد الحسين بن مستبات ماتل مسعود البغوي

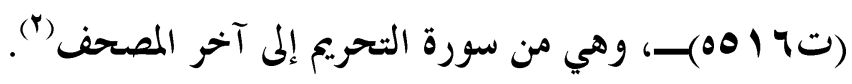

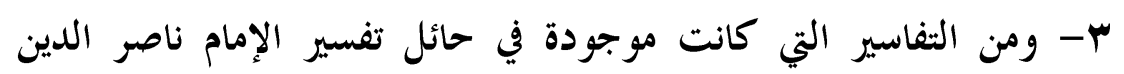

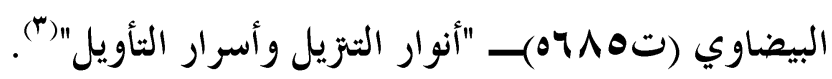

( ) لا تزال المخطوطة في مكتبة الشيخ صالح السالم البنيان بحائل. و ومما يدل على شهرته أن المطبعة

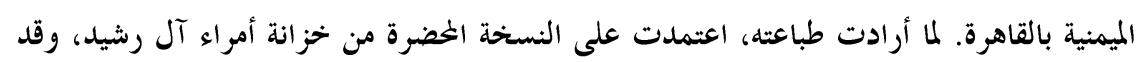

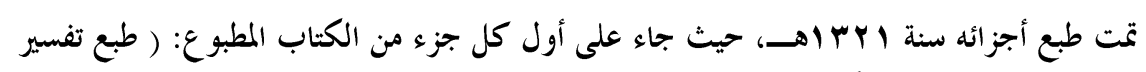

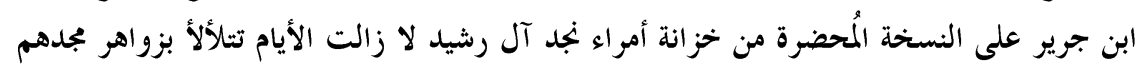

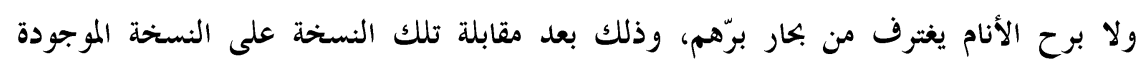

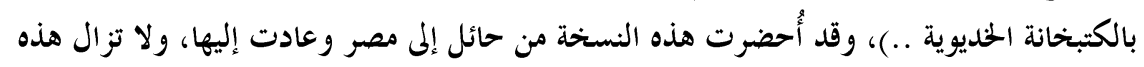

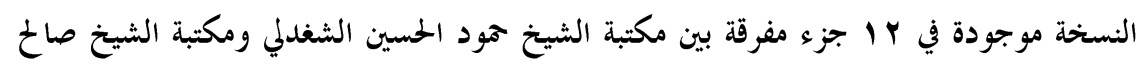

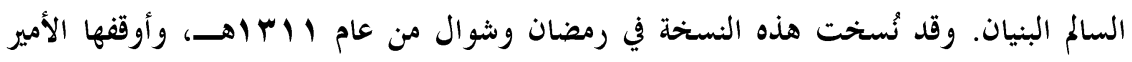

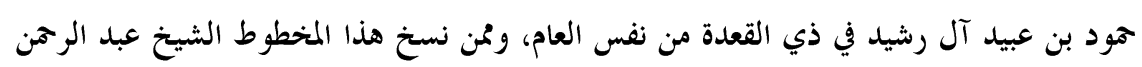

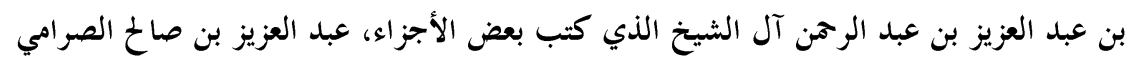

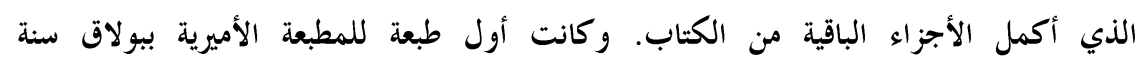

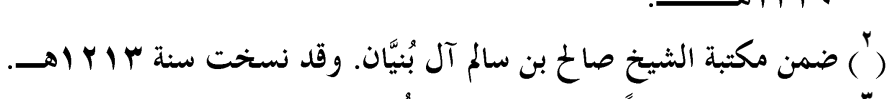

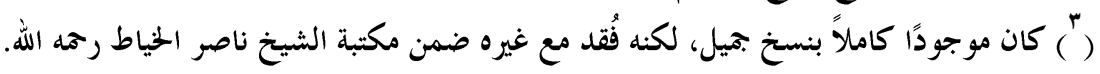


ع - تفسير النسفي "مدارك التزيل وحقائق التأويل" لعبد الله بن أحد النسفي

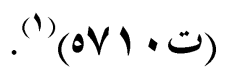

ه- نستخة من تفسير سورة الإخلاص كاملة لشيخ الإسلام ابن تيمية

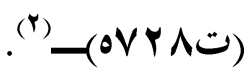

$$
\text { צ- نسخة من تفسير المعوذنين لشيخ الإسلام ابن تيمية("). }
$$

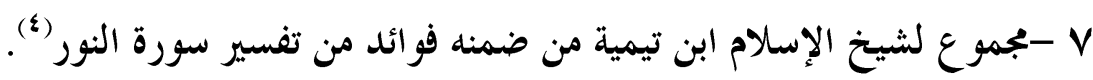

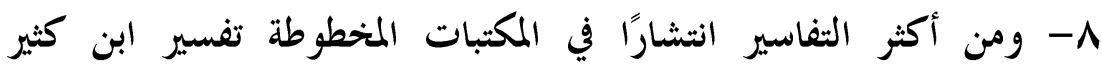

$$
\text { (•) (هV \& } \& \text { (ت) }
$$

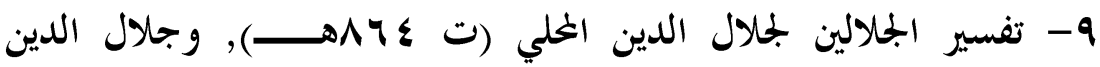

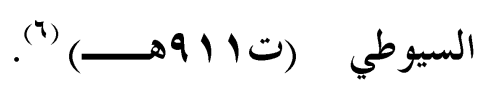

( ) 'ُسنخ في القرن الثاني عشر المجري وهو من سورة العنكبوت إلى الناس. وهو من الكتب التي أوقفها

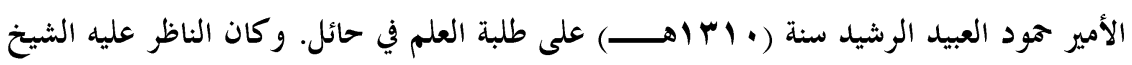

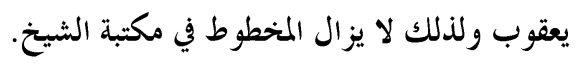

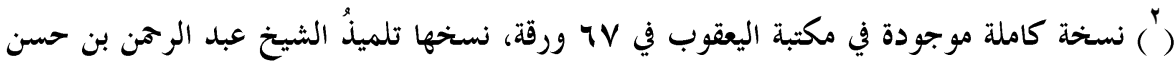

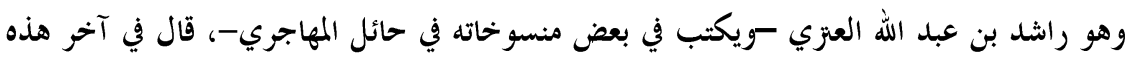

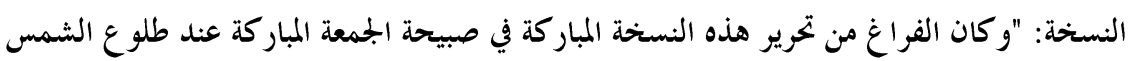

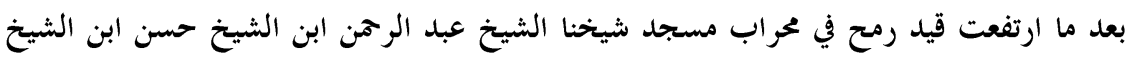

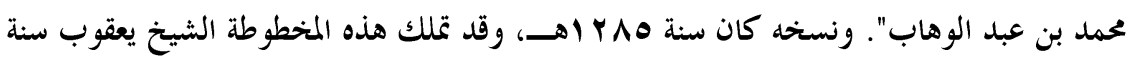

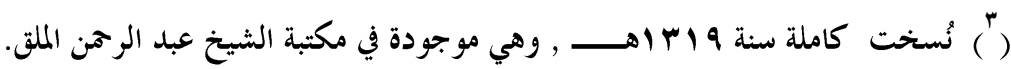

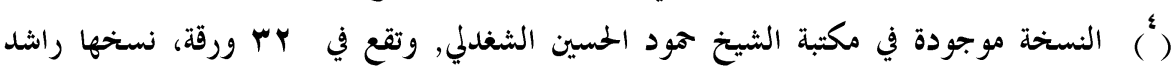
العنزي.

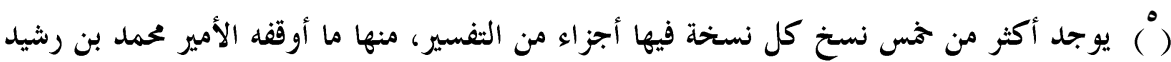

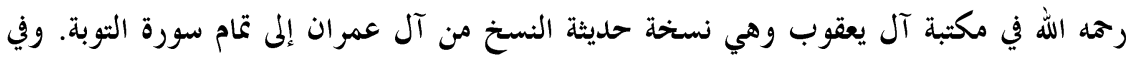

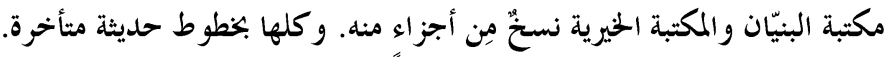

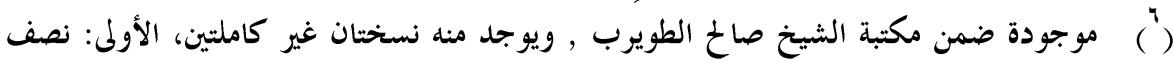


• 1-شرح لقوله تعالى:(من كان يريد الحياة الدنيا وزينتها نوف إليهم أعمالمم

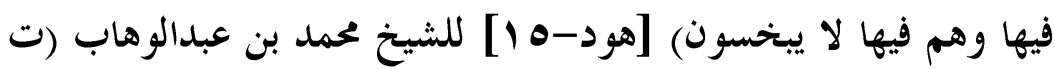

(1) (- I Y I Y

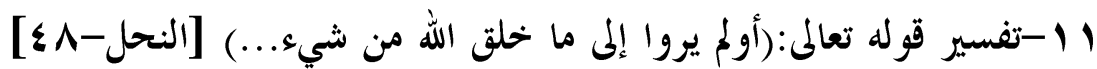

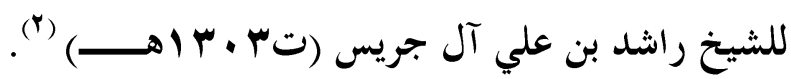

ب- مخطوطات كتب علوم القر آن:

ا - قبض البنان في ناسخ ومنسوخ القرآن، لتلميذ ابن الجوزي عبدالرحمن بن إن

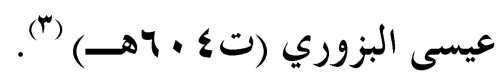

r- ومن الرسائل المنتشرة في أكثر المكتبات الخطية في حائل "التبيان في أقسام

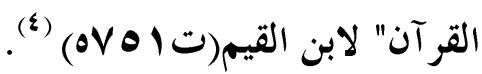

$$
\begin{aligned}
& \text { ج- مخطوطات في التجويد: }
\end{aligned}
$$

1- المقدمة الجزرية للشيخ الإمام محمد بن محمد بن محمد ابن الجزري

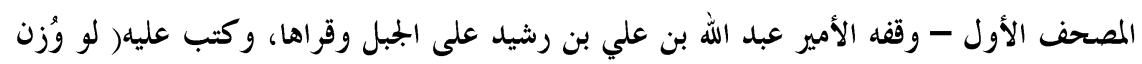

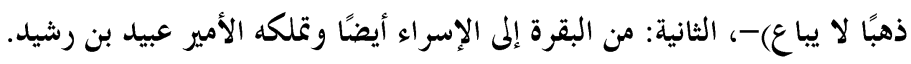

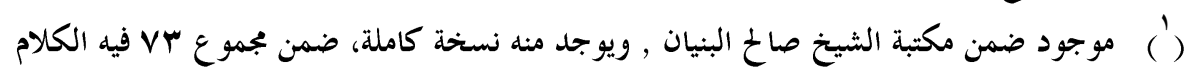

$$
\text { المنتقى وكشف الشبهات وقبض البنان وغيرها. }
$$

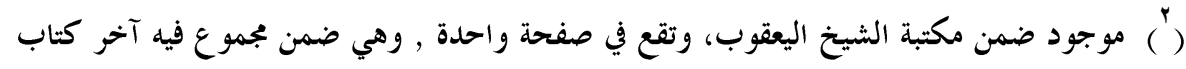

$$
\text { أفعال العباد للبخاري, وثلاثيات صحيح البخاري. }
$$

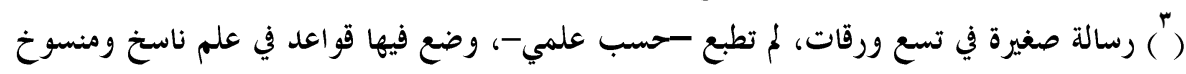

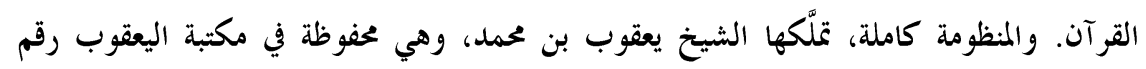

() في فائل سبع نسخ خطية موزعة على المكتبات وأكثرها بخطوط لا تتعلى القرنين السابقين قِدمًا.

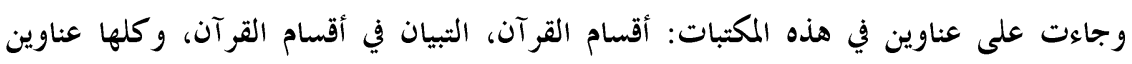

$$
\text { لمتاب واحد. }
$$




\section{(1)}

r-عنوان البيان في علم تجويد القرآن، للإمام أحمد بن محمد القسطلاّين

$$
\text { (r) (ت (ت ) }
$$

r- مرشدة المشتغلين في أحكام النون الساكنة والثنوين للشيخ ناصر الدين

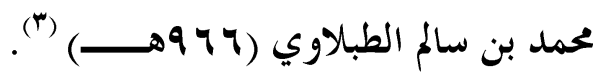

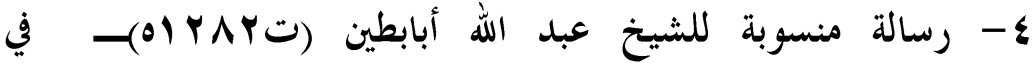

د- مخطوطات في القراءات:

1 -مخطوط في رواية حفص عن عاصم لمؤلفه أحمد بن محمد الشُفْري الحلبي (•).

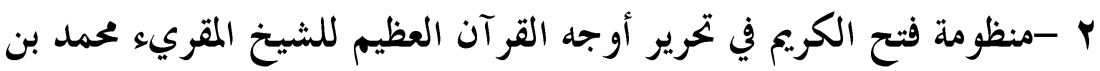

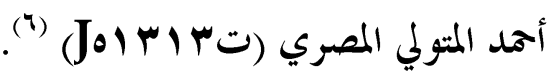

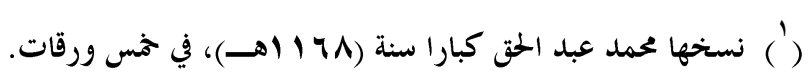

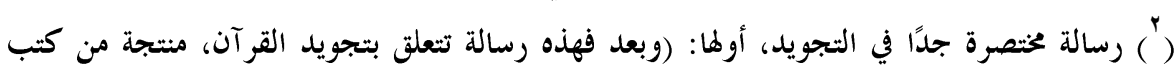

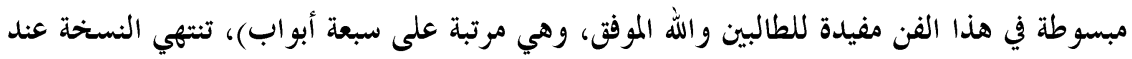

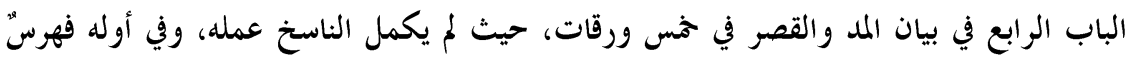

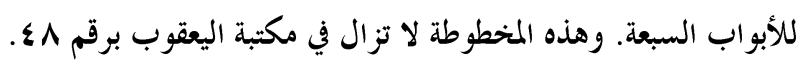

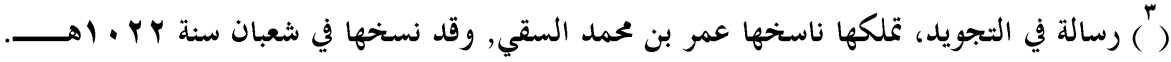

$$
\text { وهي مخطوطة ناقصة في الأخير. }
$$

() في حائل نسختان منها، الأولى: في مكتبة البنيان، والثانية: في مكتبة الطويرب، والأخيرة نسخها

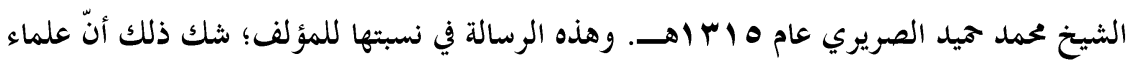

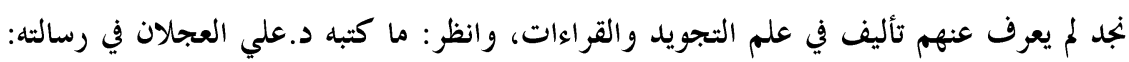

$$
\text { الشيخ عبدالله أبابطين حياته وآثاره. }
$$

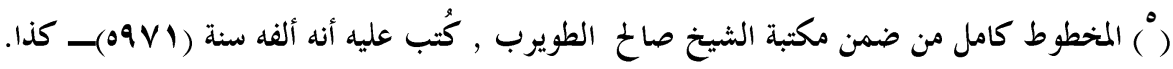

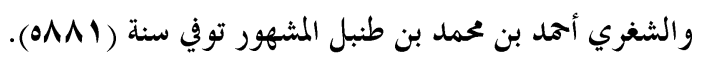

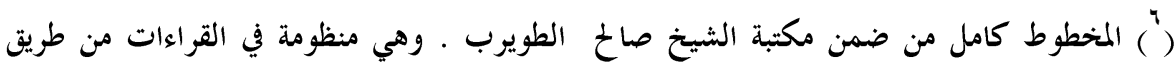

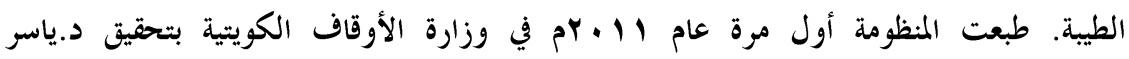




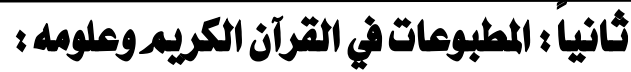

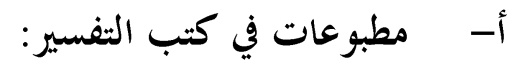

ا-تفسير جامع البيان في تأويل آي القرآن لابن جرئ آن الطبري

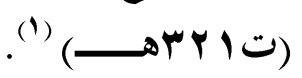

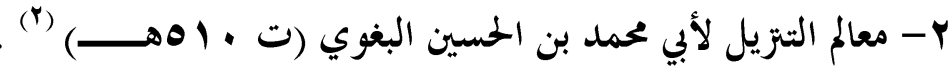

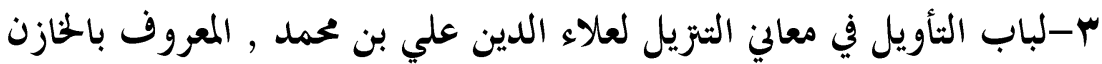

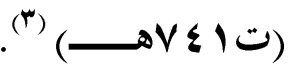

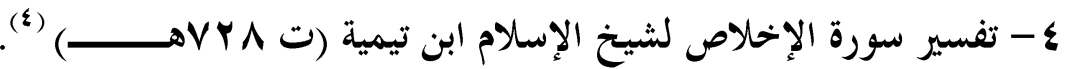

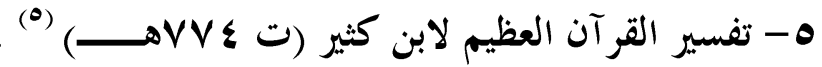

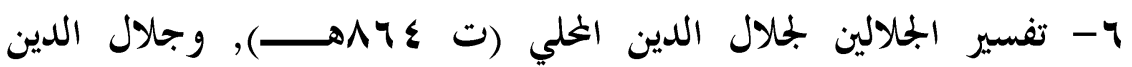

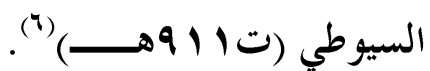

(') موجود ضمن مكتبة الشيخ حود الثغللي في عشرة مجلدات وبهامشه غرائب القرآن ورغائب

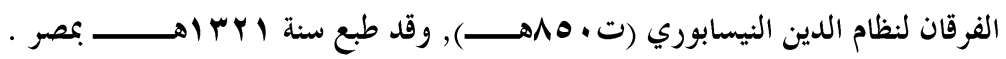

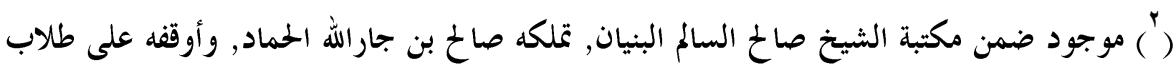

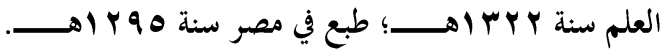

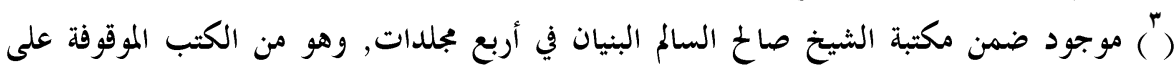

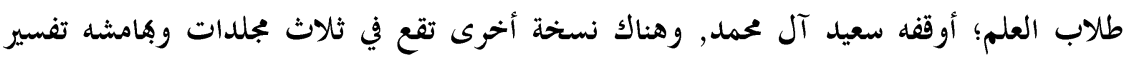
النسفي ضمن مكتبة الشيخ حمود الثغلي.

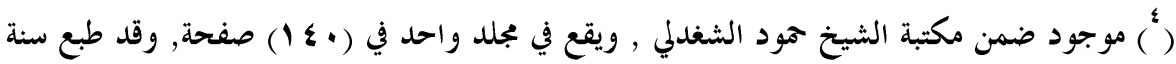

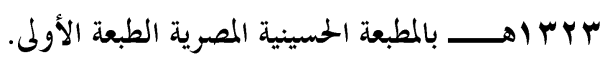
( ) هناك ثلاث نسخ ؛ اثنتان موجودتان ضمن مكتبة الشيخ صالح السالم البنيان في عشرة مجلدات

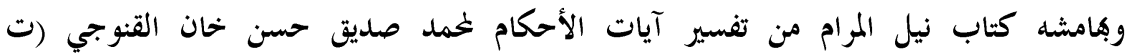
مالح.V.V

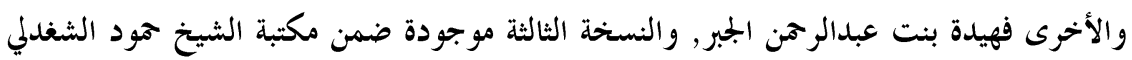

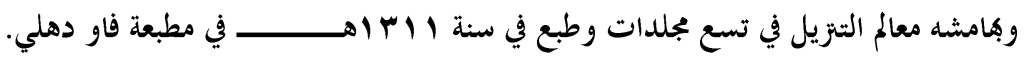

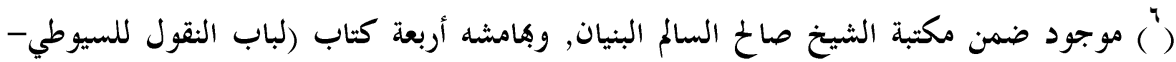




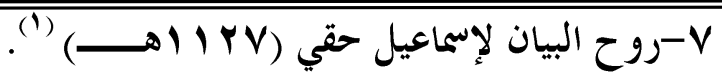

م-نيل المرام من تفسير آيات الأحكام غخمد صديق حسن خحان القنوجي (ت إن

$$
\text { (r) (ن. }
$$

ب- مطبوعات كتب علوم القر آن:

ا - إملاء ما منَّ به الرحن من وجوه الإعراب والقر اءعات في جميع القر آن لأبي

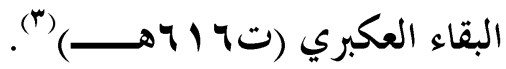

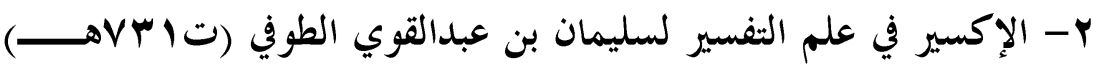

ب-الإتقان في علوم القر آن لجلال الدين السيوطي (ت ا ا وهــــ(•)

$$
\text { ج- مطبوعات كتب القراءات: }
$$

ا- المكرر فيما تواتر من القراءات السبع وتحرر لسراج الدين أبو حفص

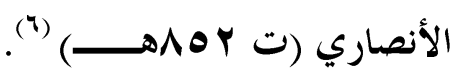

الناسخ والمنسوخ لابن حزم- ألفية أبي ذرعه في غريب القرآن- لغات القبائل الواردة في القرآن

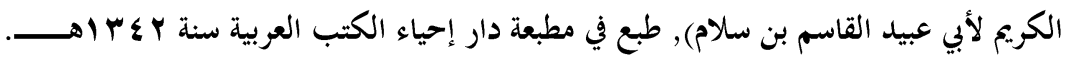

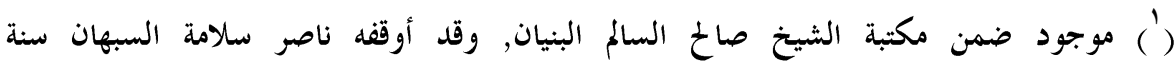

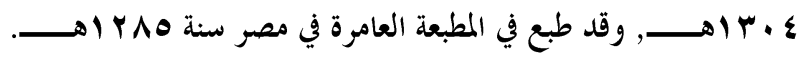

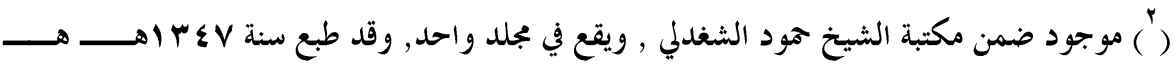

$$
\text { بالمطبعة الرحمانية بمصر. }
$$

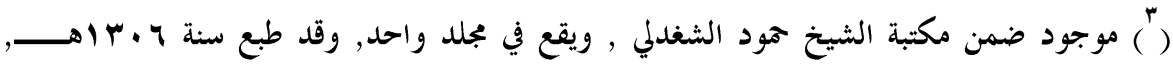

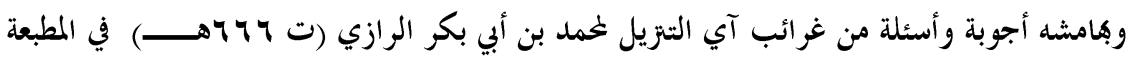

$$
\text { اليمنية بمصر. }
$$

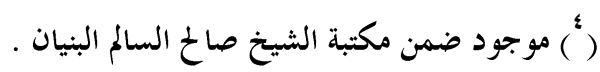

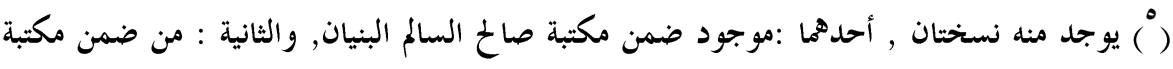

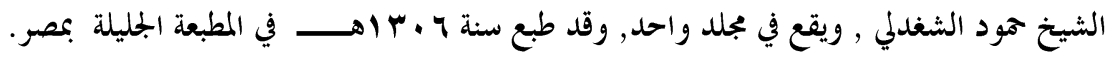

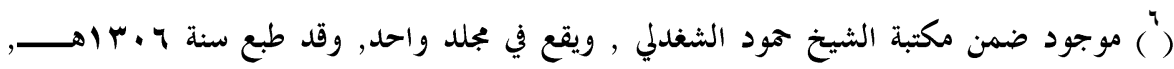

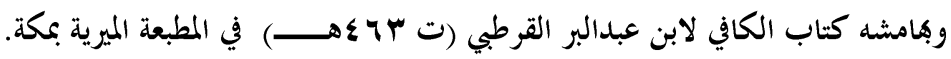




\section{الخاتمة}

1 ـ دار هذا البحث حول إسهامات منطقة حائل في خدمة القر آن الكريم

وعلومه، من منتصف القرن الثالث عشر إلى منتصف القرن الرابع عشر الفجريين، فيتحدث عن جهود الأمراء في تحت الحقبة التاريخية وجهود العلماء، والمكتبات التي حوت نوادر المخطوطات والتي كان

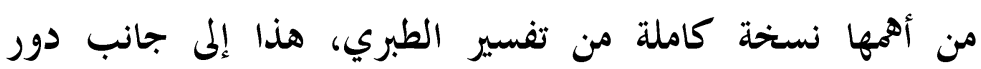

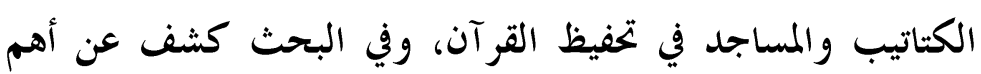
المكتبات وأشهر المخطوطات، ومشاهير علماء نجد ومدى إسهاماتم في خدمة القر آن الكريم.

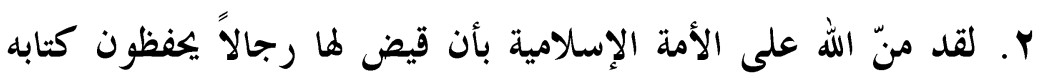
ويفسرون آياته ويبينون مشكله ويعلمونه للناس؛ فكان ذلك الإنك آلية إلهية

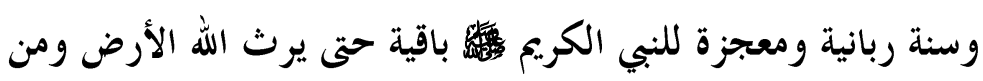

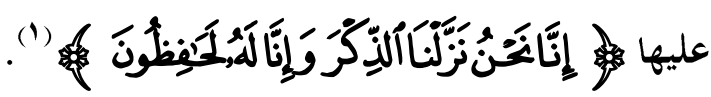

r. مكانة منطقة حائل التي ساهمت ولا تزال تساهم في إثراء الحركة

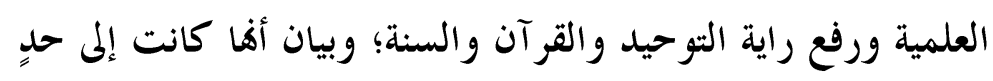

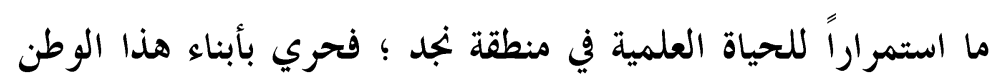

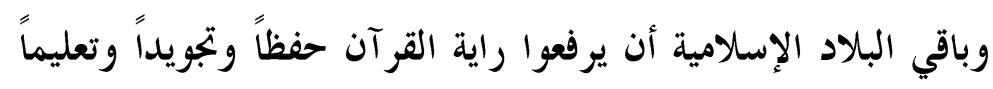

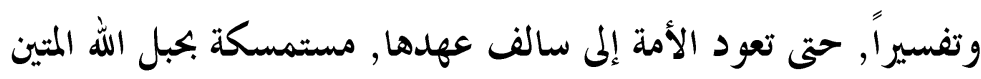

$$
\text { , ونوره المبين, والحمد لله رب العالمين. }
$$




\section{فهرس المراجع والمصادر}

آداب المعلمين, لخمد بن سحنون, تحقيق : حسن حسني عبد الوهاب -

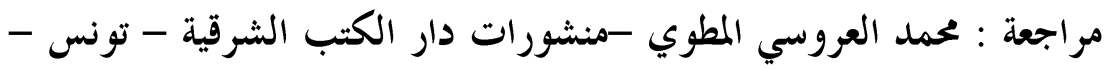

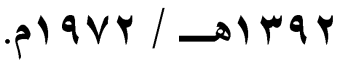

Y الأزهار الندية في تراجم طلبة العلم في الغوطة البهية ما قبل المدارس النظامية،

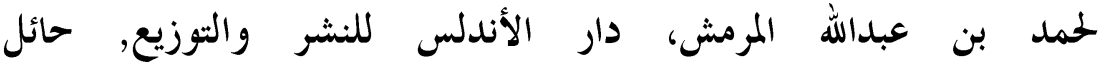

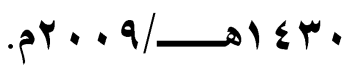

ب) الإصلاح الاجتماعي في عهد الملك، عبدالعزيز عبدالفتاح أبو علية, دارة الملك

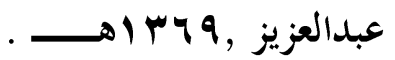

ع) الأوضاع السياسية في وسط الجزيرة العربية عند هاية القرن التاسع عشر

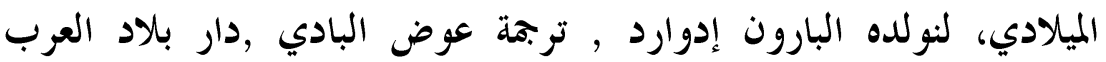

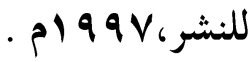

0) تاريخ نجد, لخمود شكري الألوسي، عني بتحقيقه محمد بهجة الأثري، مكتبة مدبولي، القاهرة.

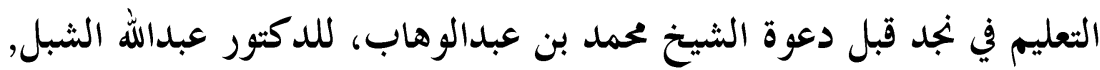

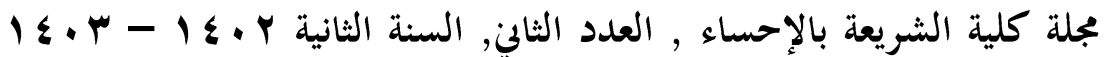

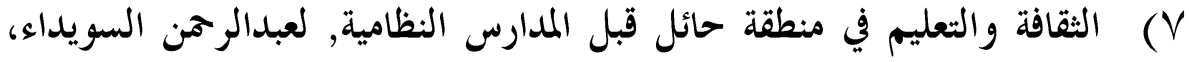

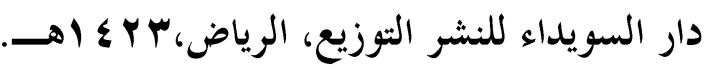

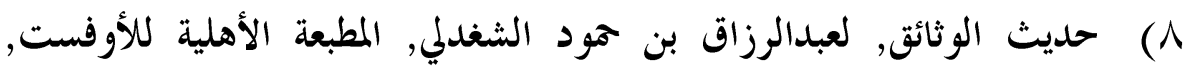

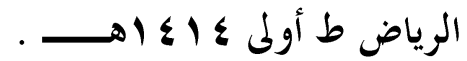

9) حكم محمد العبداللة بن رشيد لنجد, لحماد الحماد، بحث مقدم لاستكمال

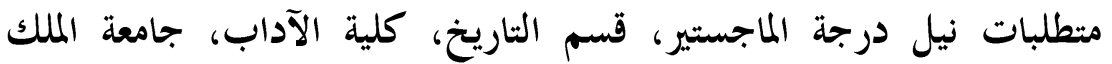

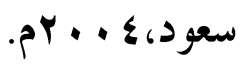

• (1) دراسة تاريخية للتعليم في إقليم نجد، لإبراهيم محمد إبراهيم، مجلة التربية 


\section{المعاصرة، ديسمبر 9NV}

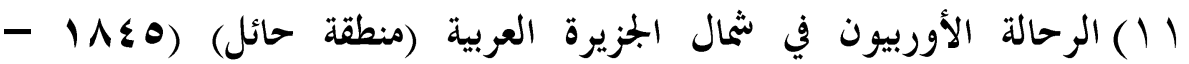
ا Y 9 (م), تحوير وتعويب عوض البادي , الناشر: دار برزان.

Y ( ) رحلة داخل الجزيرة العربية للرحالة اوتينج يوليوس, ترجمه وعلق عليه: سعيد

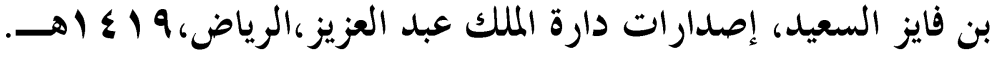

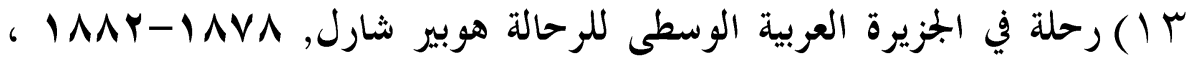

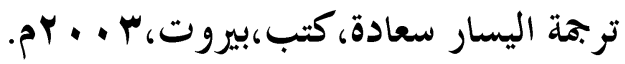
ع ( ) روضة الناظرين عن مآثر علماء نجد وحوادث السنين, عحمد بن عثمان

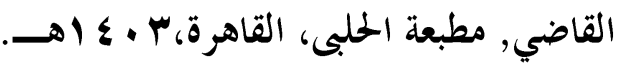
ه ) زهر الخمائل في تراجم علماء حائل، لعلي بن محمد الهندي, تحقيق إبراهيم بن

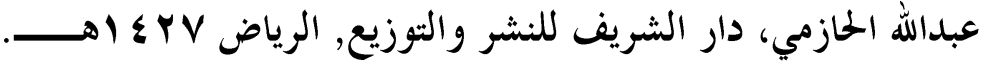
7 ( ) شعراء الجبل, لعبدالرحن بن زيد السويداء, دار الأندلس, حائل, طץ,

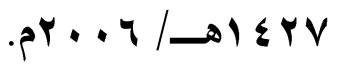

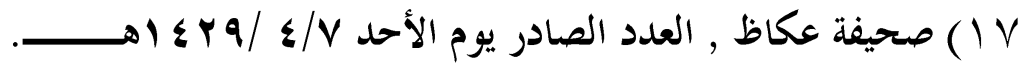
1 ( ) حور من شمالي جزيرة العرب في متصف القرن التاسع عشر للرحالة جورج

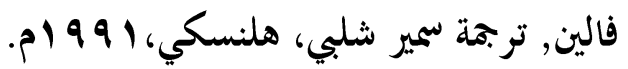
9 ( ) علماء لبدة, طرف من أخبارهم وآثارهم, لأمد العريفي، الرياض . •

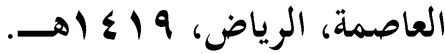
(Y) فضيلة الثيخ صالح بن سالم آل بنيان, للدكتور حسان الرديعان, دار التوحيد

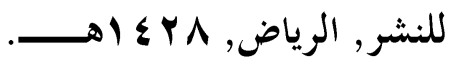

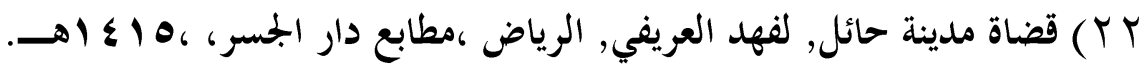

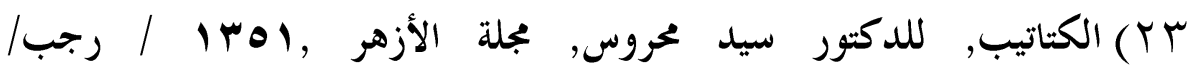


ع Y) مذكرات ضابط عثماين في نجد, لحسين حسني, ترجمة وتعليق سهيل صابان،

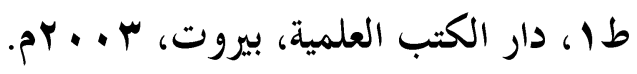

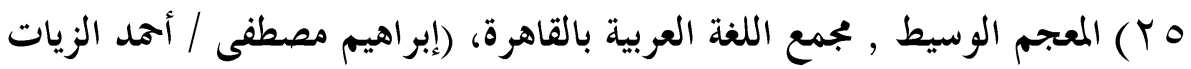

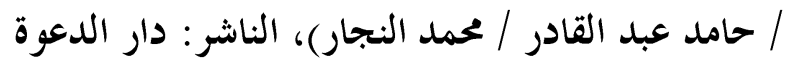

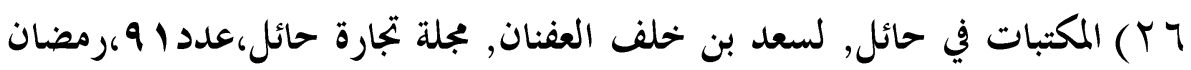

$$
\text { ـأ }
$$

منبع الكرم والشمائل في ذكر أخبار وآثار من عاش من أهل العلم في حائل، (YV

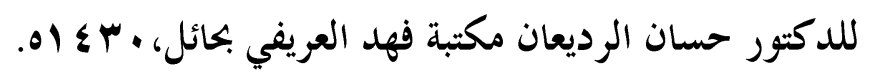

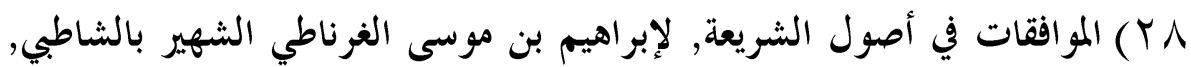

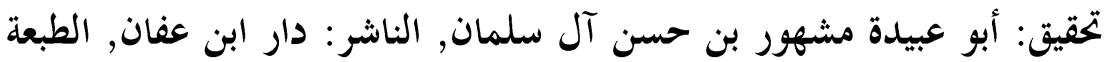

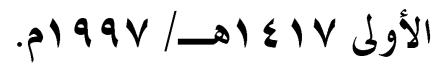

ج ج) موسوعة تاريخ التعليم في المملكة العربية السعودية في مائة عام، لوزارة

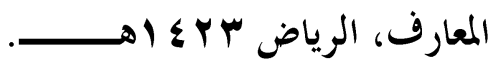

•

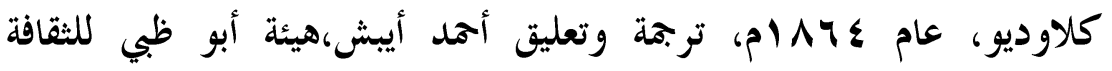

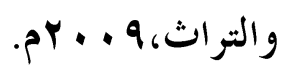

اب) نجد في الأمس القريب صور وملامح من أطر الحياة السائدة قبل ثلاثين عاماً,

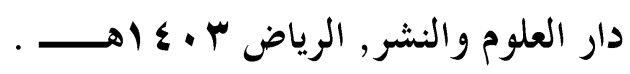

r

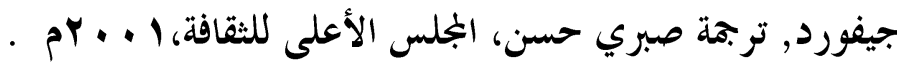

